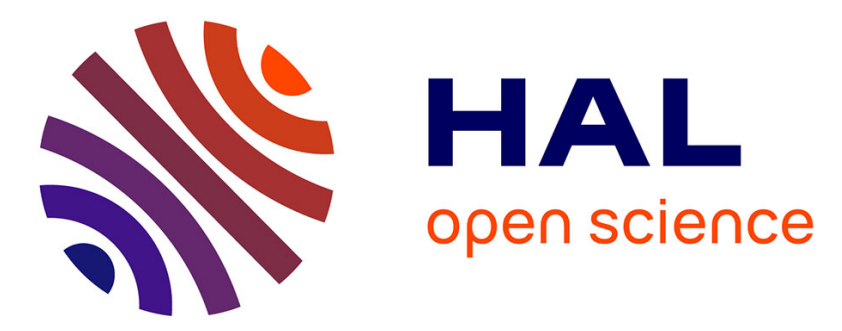

\title{
Connection between South Mediterranean climate and North African atmospheric circulation during the last 50,000 yr BP North Atlantic cold events
}

Viviane Bout-roumazeilles, N Combourieu Nebout, O Peyron, E Cortijo, A Landais, V Masson-Delmotte

\section{To cite this version:}

Viviane Bout-roumazeilles, N Combourieu Nebout, O Peyron, E Cortijo, A Landais, et al.. Connection between South Mediterranean climate and North African atmospheric circulation during the last 50,000 yr BP North Atlantic cold events. Quaternary Science Reviews, 2007. hal-03295635

\section{HAL Id: hal-03295635 \\ https://hal.science/hal-03295635}

Submitted on 22 Jul 2021

HAL is a multi-disciplinary open access archive for the deposit and dissemination of scientific research documents, whether they are published or not. The documents may come from teaching and research institutions in France or abroad, or from public or private research centers.
L'archive ouverte pluridisciplinaire HAL, est destinée au dépôt et à la diffusion de documents scientifiques de niveau recherche, publiés ou non, émanant des établissements d'enseignement et de recherche français ou étrangers, des laboratoires publics ou privés. 
1 Connection between South Mediterranean climate and North African atmospheric circulation during the last 50,000 yr BP North Atlantic cold events

3

4 V. Bout-Roumazeilles ${ }^{\mathrm{a},{ }^{*}}$, N. Combourieu Nebout ${ }^{\mathrm{b}}$, O. Peyron ${ }^{\mathrm{c}}$, E. Cortijo ${ }^{\mathrm{b}}$, A. Landais ${ }^{\mathrm{d}}, \mathrm{V}$.

5 Masson-Delmotte ${ }^{\mathrm{d}}$

${ }^{a}$ UMR CNRS 8110, Processus et Bilans des Domaines Sédimentaires, Universitéde Lille 1, 59655

Villeneuve d'Ascq Cedex, France

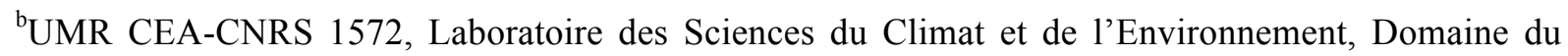
CNRS, 91198 Gif-sur-Yvette, France

${ }^{\text {}}$ UMR CNRS 6565, Laboratoire de Chrono-écologie, Universitéde Franche-Comté, 16 Route de Gray, 25030 Besançon, France

dIPSL/CEA-CNRS-UVSQ, Laboratoire des Sciences du Climat et de l'Environnement, CEA Saclay, l’Orme des Merisiers, 91191 Gif-sur-Yvette Cedex, France

${ }^{*}$ Corresponding author. Tel.: +33320434395; fax: +33320434910 .

E-mail address: viviane.bout@univ-lille1.fr(V. Bout-Roumazeilles).

\section{Abstract}

High-resolution clay mineralogical analyses were performed on sediment deposited during the last 50,000 $\mathrm{yr}$ in the Alboran sea (ODP Site 976). The clay mineral record is compared with pollen assemblages and with annual precipitation (Pann) and mean temperatures of the coldest month (MTCO) reconstructed with the modern analog technique (MAT). Enhanced contribution of palygorskite, a typical wind-blown clay mineral, characterizes the North Atlantic cold climatic events. Coeval development of the semi-arid vegetation (Artemisia rich) associated with a drastic fall of reconstructed precipitations and temperatures, suggest cold and arid continental conditions in the West Mediterranean area during North Atlantic cold events. The clay mineral association, especially the palygorskite content and the illite-to-kaolinite ratio, indicate western Morocco as one of the major source of the clay-size fraction during the North Atlantic cold events. The maximum abundance of Artemisia associated with the presence of Argania pollen both indicate Morocco as the main origin for pollen during these cold periods. The comparison of these pollen and clay mineralspecific features allows us to pinpoint western Morocco as the dominant source of wind- 
blown particles during North Atlantic cold events. These specific mineralogical composition and palynological assemblages reveal enhanced aridity over North Africa and intensification of winds favouring dust erosion and transport from North Africa toward the Alboran Sea during the North Atlantic cold events. According to atmospheric models, such a meridian transport (1) likely results from the development of strong and stable anticyclonic conditions over the tropical Atlantic and North Africa, similar to today's summer meteorological configuration and (2) implies a northward position of the westerly winds during North Atlantic cold events. Finally the synoptic situation over the West Mediterranean during the North Atlantic cold events is compared with the North Atlantic Oscillation (NAO), suggesting that during the cold Atlantic events, weather regimes over Europe and North Africa may have been systematically shifted towards a positive NAO situation.

\section{Introduction}

The Alboran Sea is a semi-enclosed basin situated in a climatic transitional area between the Atlantic Ocean and the Mediterranean Sea (Fig. 1). In the Mediterranean Sea, the formation of deep-water is mainly driven by seasonal climatic conditions: summer anticyclonic conditions favor evaporation over precipitation and dense water mass formation (Béthoux, 1980). Moreover, the displacement of European depressions over the Mediterranean creates high climatic instability and allows frequent incursions of the westerly winds. These climatic changes strongly influence the Alboran sea sedimentation: several high-resolution records reveal a millennial climate variability similar to the DansgaardOeschger events defined in Greenland ice cores (Cacho et al., 2000; Moreno et al., 2002, 2005; Sánchez-Goñi et al., 2002; Combourieu Nebout et al., 2002). The more intense cold stadials favored the northern continental ice-sheet growth, which provoked ice-calving and major iceberg discharges in the North Atlantic ocean. These so-called Heinrich events (HE) are recorded in sediments by the abundance of coarse-grain detritus associated with a typical fresh meltwater supply. Isotopic records indicate that deep convection was more efficient during cold stadials and HE than during warm interstadials suggesting an intensification of the northwesterlies during North Atlantic cold climatic events (Cacho et al., 2000). Pollen analyses reveal that arid and cold conditions develop on the surrounding continents during the HE and some cold stadials (Combourieu Nebout et al., 2002; Sánchez-Goñi et al., 2002). Moreover, grain-size and elemental analyses also suggest enhanced eolian contribution to the Alboran sedimentation during North Atlantic cold events (Moreno et al., 2002, 2005). The 
occurrence of such climatic conditions over the Mediterranean seems to be linked to the westerly regime over Europe and very similar to weather regime variations which characterize the North Atlantic Oscillation (NAO) (Rohling et al., 1998; Cacho et al., 2000; Combourieu Nebout et al., 2002; Sánchez-Goñi et al., 2002; Moreno et al., 2005). Mechanisms, however, are still unclear. In order to understand the links between the cold climatic events recorded in Greenland ice core (Johnsen et al., 1992) and the climatic changes over the Mediterranean area and North Africa, high-resolution mineralogical analyses of sediments from the ODP Site $976(36112 \mathrm{~N}, 4118 \mathrm{~W})$ were performed on the 0-50 ka interval. Indeed previous studies in the tropical Atlantic Ocean demonstrated that mineralogy could successfully be used to trace the source and transport of wind-blown particles (Caquineau et al., 1998). Our main objective is then to trace the variations of dust emission and transport over North Africa and South-West Mediterranean related to the North Atlantic Marine Isotopic Stage 3 cold events (Dansgaard-Oeschger stadials and HE). The composition of the clay mineral fraction is also compared to pollen assemblages in order to reconstruct the western Mediterranean oceanic and continental paleoenvironments and climate changes during the last 50,000 yr BP.

\section{Eolian input, atmospheric scenario and clay mineral transport}

The eolian supply contributes significantly to the terrigenous marine sedimentation and can then be used to trace the climatic evolution of continental areas (Sarnthein et al., 1982; Ruddiman et al., 1989). But the dust transport shows strong seasonal variability in occurrence, origin, trajectories and composition (Prospero et al., 1981; Pye, 1987; Chiapello et al., 1997; Moulin et al., 1997; Grousset et al., 1998; Ratmeyer et al., 1999).

\subsection{Eolian and riverine contribution to deep-sea sediments}

Sedimentation in the Mediterranean Sea is mainly terrigenous due to the vicinity of the surrounding continents associated with important riverine and eolian supplies. At present-day a major part of detrital clays is supplied via rivers (Milliman and Meade, 1983; Stanley et al., 1992). In the eastern Mediterranean, most particles (120.106 t/yr) are provided by the Nile River. The Rhone River with an annual discharge of $31.106 \mathrm{t} / \mathrm{yr}$ is the main contributor to sedimentation in the northwestern Mediterranean whereas the Po River (13.106 t/yr) and the Ebro River (18.106 t/yr) are of minor influence. 
The eolian contribution to deep-sea sediments has been demonstrated in several studies (Prospero, 1981a, b; Pye, 1987) especially in Mediterranean fine-grained fraction (Tomadin and Lenaz, 1989; Matthewson et al., 1995; Guerzoni and Chester, 1996). Because mineral aerosols can be long-range transported (Rea et al., 1985; Guerzoni and Chester, 1996), massive plumes of desert dust are exported to the Atlantic Ocean and to the Mediterranean all year long. There is still a debate about the atmospheric contribution to deep-sea sediments with estimations ranging from 10\% to 50\% (Loye-Pilot et al., 1986; Guerzoni et al., 1997). In fact, the eolian supply is generally estimated to be one order of magnitude lower than fluvial supply at the scale of the whole Mediterranean basin (3.9.106 t/yr) (Bergametti et al., 1989c). This value probably underestimates the real contribution of eolian supply since an important part of river material may be trapped on the continental shelf on the West Mediterranean (Sarnthein et al., 1982; Ratmeyer et al., 1999). Previous studies based on radionucleides (Gascó et al., 2002) and trace metal budget (Elbaz-Poulichet et al., 2001) concluded that sedimentation in the western Mediterranean and in the Alboran Sea is significantly fed by eolian particles compared to riverine inputs. This characteristic results both from a rather low fluvial discharge from the Ebro River compared to other periMediterranean rivers and from extended desert areas (Sahara and Sahel) seasonally exposed to strong winds, which provide huge amounts of dust particles to the atmosphere (Prospero, 1981a; Coudé-Gaussen, 1982; Middleton, 1985; Pye, 1987).

\subsection{Dust origin}

Arid regions such as the Sahara and semi-arid regions such as northern North Africa or Sahel provide dust particles to the Atlantic Ocean and the Mediterranean Sea (Prospero et al., 1981; Coudé-Gaussen, 1982; Matthewson et al., 1995). Grain-size analyses of windblown dust reveal two populations characterizing different source areas and transport mechanisms. Although major dust emission are generally situated in the subtropical desert belt and in semiarid regions (Pye, 1987; Chamley, 1989 and references therein), grain-size distribution reveals that the coarsest fraction is remobilized from Saharan dunes whereas the finer size fraction originates from paleosols and little consolidated formations located on the southern and northern borders of the desert (Rognon et al., 1996). The largest particles are typical of dust storm and are generally transported by trade winds below $100 \mathrm{~km}$ of altitude, being restricted to continental and adjacent marine areas (Torres- Padrón et al., 2002). By contrast, the fine-grained particles $(02 \mathrm{~mm})$ move over long distances as high-altitude 
aerosols (Schu“tz, 1980). Finally satellite-derived data as Infrared Dust Differencing Index (IDDI) and Total Ozone Mapping Spectrometer (TOMS) suggest that the Bodélédepression in Chad (Brooks and Legrand, 2000; Washington and Todd, 2005) and West Sahara and more generally topographic lows are among the most present-day dust productive areas.

\subsection{Wind systems}

The modern atmospheric circulation (Fig. 1) over North Africa is mainly controlled by the northeast trade winds (TW) and by the mid-tropospheric Saharan Air Layer (SAL) (Grousset et al., 1992; Matthewson et al., 1995). The resulting southern Saharan winds are mono-directional with a general westward transport. The dust plume extension is seasonally modulated by the migration of the Inter-Tropical Convergence Zone (ITCZ) (Prospero et al., 1981; Pye, 1987; Torres-Padrón et al., 2002). In winter, when the ITCZ occupies its southernmost position at 81N (Prospero et al., 1981; Pye, 1987), Saharan dust originates from southern Sahara and Sahelian regions and is transported toward the tropical Atlantic Ocean by the northeast trade winds (Schütz, 1980; Coudé-Gaussen et al., 1987; Bergametti et al., 1989b; Grousset et al., 1992, 1998; Matthewson et al., 1995; Chiapello et al., 1995, 1997; Moulin et al., 1997). In summer, trade winds are geographically restricted due to the northern migration of the ITCZ $(201 \mathrm{~N})$. Intensive insolation over Sahara creates strong surface winds and large-scale convection which lifts particles to the high atmosphere $(5 \mathrm{~km})$. Particles originating from western and central part of the Sahara (e.g. Torres-Padrón et al., 2002) are transported at high-altitude by the SAL (Fig. 1), above the trade wind inversion toward the tropical Atlantic (Schütz, 1980; Coudé-Gaussen et al., 1987). A north-turning part of the SAL moves (NSAL) into an anticyclonic gyre along the African coast (Fig. 1) and reaches the Mediterranean (Prospero et al., 1981; Bergametti et al., 1989b).

By contrast, winds (Fig. 1) are pluri-directionnal in northern Sahara (Coudé-Gaussen et al., 1982). Their trajectories depend on the relative position of both high and low-pressure systems over the Atlantic Ocean, the Mediterranean and on the westerly wind regime over Europe (Coudé-Gaussen et al., 1982; Bergametti et al., 1989c; Moulin et al., 1997; Rodríguez et al., 2001). Dust transport is sporadic in nature but a single event can account for more than $50 \%$ of the annual eolian flux (Guerzoni et al., 1997). Such meridian transports occur when the westerly regime is weak or disrupted and are more frequent during summer (CoudéGaussen et al., 1982; Guerzoni et al., 1997; Rodríguez et al., 2001; Torres- Padrón et al., 2002; Ginoux et al., 2004). Three main atmospheric configurations (Fig. 2) favor the transport 

et al., 1987; Bergametti et al., 1989c; Rodríguez et al., 2001): (1) a SW-NE transport (Fig. 2a) toward the northern part of the Mediterranean occurs mostly in winter when a large depression system develops between Canary Islands and the Iberian Peninsula; (2) during interseason, a SE-NW transport (Fig. 2b) is initiated by the simultaneous occurrence of a strong central European anticyclone and of a depression off Portugal; (3) summer dust transport (Fig. 2c) mainly results from the westward shift of the North African anticyclone associated with the remoteness of the Azores high, which provides a SW-NE depression trench along the African coasts toward the Iberian Peninsula and western part of the Mediterranean.

\subsection{Clay mineral sources}

In order to understand the variations of the clay mineralogy in sediments from the Alboran Sea, the clay mineral assemblages of main source areas were reconstructed using previously published and unpublished data in the frame of the general fluvial, oceanic and atmospheric patterns (Fig. 3). The clay mineralogy of various Mediterranean marine sites has been studied in several marine cores (e.g. Chamley, 1989; Foucault and Mélières, 2000). On average sediments from the western Mediterranean are dominantly composed of $50 \%$ illite and $25 \%$ kaolinite, with lower amount of smectite $(15 \%)$ and chlorite $(10 \%)$ whereas fibrous clays (palygorskite) are present as trace amounts.

Illite generally represents the relative contribution of physical weathering to sedimentation, because this mineral is resistant to degradation and to transport (Chamley, 1989). In the northern Mediterranean (Fig. 3a) the Rhone River and the Po River receiving their detrital material from the Alps are particularly rich in illite associated with some chlorite. As a result, illite dominates the clay mineral association of sediments from the Gulf of Lion (80\%) and from the Adriatic Sea (60\%) (Tomadin, 2000). Illite is also a major component (35\%) of the Ionian Sea sediments (Chamley, 1989) and of the Ebro sedimentary system (35\%) (Alonso and Maldonado, 1990). On the North African continent, the relative abundance of illite displays a north-south gradient: illite constitutes $60 \%$ of the clay mineral assemblage in northern Algeria, 50\% in central Sahara and less than 30\% in the Sahelian zone

192 (Paquet et al., 1984). As a result, dust-blown (Fig. 3b) particles originating from Western

193 Sahara are richer in illite $(60 \%)$ than the particles $(30 \%)$ issued from central and southern

194 Sahara (Avila et al., 1997). 
Kaolinite mainly forms through hydrolysis processes and is typical of highly weathered environment (e.g. Chamley, 1989) such as well-drained lateritic soils characterizing equatorial regions (e.g. Chamley, 1989). Kaolinite (Fig. 3) is thus rare (10\%) and reworked from ancient formations in the Rhone and Nile river sediments and even absent in the Po river (e.g. Chamley, 1989), whereas it is much more abundant (30\%) in the Ebro river which drains kaolinite rich deposits (Alonso and Maldonado, 1990). In North Africa the distribution of kaolinite depends on the latitude (Paquet et al., 1984): trace amounts in the northern and westernmost part of North Africa, more common in central and South Sahara and abundant in Sahelian and equatorial regions (Pastouret et al., 1978; Caquineau et al., 1998). Moreover kaolinite (Fig. 3b) is more abundant in dust originating from eastern Sahara compare to western Sahara (Guerzoni et al., 1999).

In a general way, smectite is not abundant in the western part of the Mediterranean (Fig. 3a) as a result of the increasing distance from the Nile River, which is the main contributor of smectite in the Mediterranean. The Po and Rhone Rivers do not transport more than $20 \%$ of smectite but small Italian coastal and Pyrenean rivers may, respectively, contribute to the supply of smectite in the Tyrrhenian Sea and in the Gulf of Lion (e.g. Chamley, 1989; Foucault and Mélières, 2000). Smectite is rare in the northern Sahara whereas it is abundant in southern Sahara and Sahel. In these areas, smectite may represent $70 \%$ of the clay mineral fraction and is associated with kaolinite issued from ancient lateritic profiles (Sarnthein et al., 1982; Paquet et al., 1984; Chamley, 1989). In agreement with this latitudinal distribution, dust originating (Fig. 3b) from western Sahara and Moroccan Atlas are depleted in smectite compared to dust originating from central Algeria and Sahelian sources (Avila et al., 1997).

Although chlorite is often associated with illite, it is far less resistant to weathering and transport. Chlorite thus mainly reflects the composition of nearby source area (Chamley, 1989). In the northwestern part of the Mediterranean basin, the main source of chlorite is the Ebro sedimentary system (35\%) (Alonso and Maldonado, 1990) whereas the respective contribution of the Rhone and the Po river is of minor importance (e.g. Chamley, 1989).

Palygorskite is characteristic of the sub-arid belt of the northern hemisphere (Singer and Galan, 1984; Chamley et al., 1989) where its formation is favored by chemically restricted conditions (Singer and Galan, 1984). For instance, evaporation and chemical concentration provide the formation of palygorskite (Fig. 3a) on poorly drained carbonated rocks in the anti-Atlas (El Mouden et al., 2005). But elongated fibers of palygorskite are 
usually destroyed during fluvial transport (Chamley, 1989; Snoussi et al., 1990). As a result there are some discrepancies (Fig. 3a) between the composition of the source area and of the mineralogical assemblages recorded in the downstream alluvial sediment (El Mouden et al., 2005). Palygorskite from recent marine deposits off Africa is commonly considered to be dust-blown particles reworked from Neogene North African deposits (e.g. Chamley, 1989). Palygorskite can be distributed through eolian processes over long-range distance as far as

234 Scotland and has been used to trace the Saharan origin of dust (Coudé-Gaussen et al., 1982;

235 Molinaroli, 1996). At present-day, Sahara winds are reported to carry sporadically noticeable amounts of palygorskite over the whole Mediterranean basin (Coudé-Gaussen and Blanc, 1985). For example, some Tunisian loess's are composed of $45 \%$ of palygorskite (Grousset et al., 1992). Robert et al. (1984) identified up to $25 \%$ of African-derived palygorskite associated to kaolinite in sediments from a high-altitude lake in Corsica (Fig. 3b). Palygorskite represents $10-15 \%$ of the clay mineral fraction in northern Algeria (Paquet et al., 1984), $10-25 \%$ on the central Algeria and less than $10 \%$ in the southern Sahara (Paquet et al., 1984). Similarly, dust from central Algeria and western Sahara (10\%) and Morocco Atlas $(17 \%)$ contain lower amounts of palygorskite than dust deposited (Fig. 3b) in northern Morocco (up to 75\%) (Avila et al., 1997).

\section{Material and methods}

\subsection{Stratigraphy}

ODP Site $976\left(36^{\circ} 12 \mathrm{~N}, 41^{\circ} 8 \mathrm{~W}, 1108 \mathrm{~m}\right.$ depth) is located in the Alboran Sea, close to the Atlantic-Mediterranean gateway (Fig. 1). Chronology is first based on 17 AMS14C ages (Combourieu Nebout et al., 2002), and then on a correlation between the oxygen isotopes record of site 976 and core MD95-2042 (Cacho et al., 2000) and secondly on correlation

252 between the pollen temperate records of site 976 and $\delta^{18} \mathrm{O}$ of ice from the NorthGRIP ice core (NorthGRIP members, 2004). This age scale does not enable us to estimate precisely the vegetation response time compared with the ice-core record, occurring within a few decades to centuries (Masson-Delmotte et al., 2005). Here, we present the uppermost 25m that span a time interval corresponding to the last 50,000 yr. 
All samples were first decalcified with $0.2 \mathrm{~N}$ hydrochloric acid. The excess acid was removed by $\mathrm{H} 2 \mathrm{O}$ washing and repeated centrifugations. The clay-sized fraction $(\mathrm{o} 2 \mathrm{~mm})$ was isolated by settling, and oriented on glass slides (oriented mounts). Three X-ray diffraction (XRD) determinations were performed: (a) untreated sample; (b) glycolated sample (after saturation for $12 \mathrm{~h}$ in ethylene glycol); (c) sample heated at $49^{\circ} \mathrm{C}$ for $2 \mathrm{~h}$. The analyses were run on a Philips PW 1710 X-ray diffractometer between 2.49 and $32.51^{\circ} 2$ theta Each clay mineral is then characterized by its layer plus interlayer interval as revealed by XRD analysis. Smectite is characterized by a peak at $14 \AA$ on the untreated sample test, which expands to $17 \AA$ after saturation in ethylene glycol and retracts to $10 \AA$ after heating. Illite presents a basal peak at $10 \AA$ on the three tests (natural, glycolated and heated). Chlorite is characterized by peaks at $14,7,4.72$ and $3.53 \AA$ on the three tests. Kaolinite is characterized by peaks at 7 and $3.57 \AA$ on the untreated sample and after saturation in ethylene glycol. Both peaks disappear or are strongly reduced after heating. Palygorskite presents a basal peak at $10.34 \AA$ accompanied by a weaker peak at $6.44 \AA$, on both untreated and glycolated tests. The $10.34 \AA$ peak collapses at $10 \AA$ after heating (Brindley and Brown, 1980). The presence of palygorskite has been confirmed by MET observations of the palygorskite-rich samples. Semi-quantitative estimation of clay mineral abundances, based on the pseudo-Voigt deconvolution for the

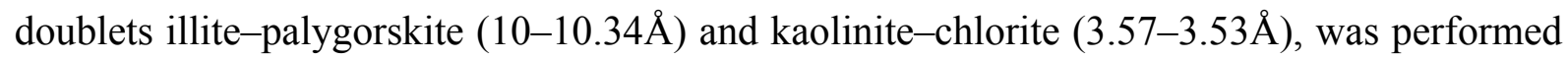
using the software MacDiff developed by Petschick (2000).

\subsection{Pollen analyses and quantitative climate reconstruction}

Micropaleontological analyses were performed on the size fraction $0125 \mathrm{~mm}$, and more than 300 specimens were counted per sample. Pollen methodology follows a classic protocol already developed by Combourieu Nebout et al. (2002). More than a hundred pollen, excluding Pinus were counted per sample for paleoenvironmental interpretation. Paleoenvironmental interpretation of the downcore pollen assemblage fluctuations is based on the assumption that the primary pollen contribution to Alboran Sea sediments comes from western Mediterranean borderlands. Modern environments range from a thermoMediterranean belt with Olea, Pistacia and some steppe or semi-desert representatives (Artemisia, Ephedra), to a meso-Mediterranean belt, represented by a sclerophyllous oak forest to a humid-temperate oak forest (mainly Quercus associated with Ericaceae), to a supra-Mediterranean belt, with a cold-temperate coniferous forest (Pinus, Abies, Cedrus) at the higher altitudes (Ozenda, 1975; Rivas-Martinez, 1982). 
Around 120 pollen taxa were identified ranging from semi-desert to mountain

293 deciduous and coniferous forest. Their interpretation follows the modern climatic-plant relationships in Eurasia and northern Africa (e.g. Peyron et al., 1998). Here we present the variations of pollen percentages of two main associations: (1) the temperate association composed of European-Siberian trees such as Quercus, Fagus, CarPinus, Corylus, Alnus, Betula, Tilia and Ulmus associated with Ericaceae, reflecting the warmer and moist climate characteristics of interstadials, and (2) the steppe to semi-desert association, composed of Artemisia and Ephedra, which marks the dry and cold climatic conditions of the stadials. The analog technique has been applied to the ODP 976 fossil pollen assemblages to provide quantitative estimates of temperatures and precipitation during the last 50,000 yr BP (Guiot, 1990). First developed for continental pollen sequences, the MAT has been tested with success to marine pollen cores from the Mediterranean region (Desprat et al., 2005). In this method, similarity between fossil and modern pollen assemblages is evaluated by a chord distance calculated as a $\mu \mathrm{m}$ of differences between log-transformed percentages of the taxa. Such method does not imply a direct analogy between modern and fossil assemblages, although the quality of the results depends on the size and diversification of the modern data set (Peyron et al., 1998). Here, this technique is based on a modern pollen database including 1510 modern pollen spectra mainly located in the Mediterranean basin (especially Spain and Morocco), Europe and Eurasia (Peyron et al., 1998). Since Pinus is overrepresented in marine sediments, this pollen type has been removed from the marine pollen counting as well as from the continental pollen database. The 10 modern spectra which have the smallest chord distance are considered as the best modern analogs of the given pollen spectrum, and used for the reconstruction. The climatic parameters of the 10 best modern analogs are averaged by a weighting inverse to the chord distance. Here, the climatic parameters reconstructed are the mean temperature of the coldest month $\left({ }^{\circ} \mathrm{C}\right)$ and annual precipitation $(\mathrm{mm} / \mathrm{yr})$. The error is computed as lower and upper limits of positive and negative deviation of extreme analogs compared to the mean value.

\section{Results}

\subsection{Clay minerals}

The average composition of the clay mineral fraction $(<2 \mu \mathrm{m})$ of the uppermost part of the ODP site 976 (0-25m composite depth), which records the last 50,000 yr, is composed of $33 \%$ illite, $31 \%$ smectite, $16 \%$ kaolinite, $15 \%$ chlorite and 5\% palygorskite. All clay minerals 
show several oscillations during the last glacial period whereas their abundances are less variable during the Holocene (Fig. 4). This apparent weak variability may result from significantly lower sampling resolution within the Holocene (one sample per $500 \mathrm{yr}$ ) compared with the last glacial stage (one sample per $300 \mathrm{yr}$ ). These results are in good agreement with previous mineralogical studies in the Alboran sea (e.g. Chamley, 1989; Martínez-Ruiz et al., 1999).

Illite represents $28-40 \%$ of the total clay mineral fraction. The illite record is characterized by high frequency oscillations of moderate amplitude throughout the core, slightly lower during the Holocene (Fig. 4a). The illite content is maximum around 27 and $22.5 \mathrm{ka}(\mathrm{H} 2)$ whereas it is minimum around $35 \mathrm{ka}, 30 \mathrm{ka}(\mathrm{H} 3), 23.5,20.5,18,13.5,10$ and 7 ka.

The percentages of smectite range between $19 \%$ and $42 \%$. The average smectite content decreases slightly between 50 and $22 \mathrm{ka}$. High-frequency variations are added to this general decreasing trend (Fig. 4b). The relative abundance of smectite is especially low around 38, 32.5, 26 and 20/22 $\mathrm{ka}(\mathrm{H} 2)$, and reaches minimum values around $15 \mathrm{ka}(\mathrm{H} 1)$. Smectite is abundant around 39, 27.5, 18 and 12 ka reaching maximum values around $36 \mathrm{ka}$.

The kaolinite record varies between $11 \%$ and $24 \%$. The average content of kaolinite increases from last glacial $(<15 \%)$ to the Holocene $(<20 \%)$. There is no consistent evolution either during the North Atlantic cold events: an increase of kaolinite is associated with $\mathrm{H} 1$ whereas kaolinite is low during H2-H4 (Fig. 4c).

The abundance of chlorite varies between $10 \%$ and $22 \%$ throughout the core. The chlorite content is higher between 22 and $12 \mathrm{ka}$ than over the rest of the core. High-frequency oscillations overwhelm a slightly increasing trend between 50 and $22 \mathrm{ka}$. Minimum percentages of chlorite are associated with the HE and with the Younger Dryas (Fig. 4d).

Palygorskite composes $3-11 \%$ of the clay mineral fraction. The record is characterized by the presence of several significant peaks, out of the standard deviation range (Fig. 4e). Most of these peaks are associated with cold climatic events, YD and HE (Fig. 4e). H1 and H4 are especially enriched in palygorskite. Except these peaks the record is quite smooth and show very little variations. We can notice a reduce amount of palygorskite during the Holocene.

\subsection{Pollen}


Palynological records from ODP Site 976 document the classic climatic trend in the Mediterranean region from the glacial times to the Holocene (e.g. Reille and Lowe, 1993; Watts et al., 1996; Allen et al., 1999; Combourieu Nebout et al., 2002; Sánchez-Goñi et al., 2002; Roucoux et al., 2005; Tzedakis, 2005). Variability of pollen assemblages reflects repetitive alternations between temperate forest (mainly Quercus), very similar to today's vegetation in the mountains of the western Mediterranean, and semi-desert vegetation as observed today in North African and South- Eastern Europe (Walter et al., 1975) (Fig. 5).

Elevated abundance of temperate pollen taxa occur during warm interstadials, indicating warm and humid climates on continents adjacent to the Alboran sea. Cold stadials correlate with increased Artemisia pollen relative abundance that is indicative of enhanced continental aridity (Fig. 5) (Combourieu Nebout et al., 2002). Periods of maximum cooling in the North Atlantic, the HE H1 to H5, are reflected at Site 976 by coeval maxima of semi desert- rich Artemisia and minima of Quercus forest. Such associations are characteristic of cold steppe to cold desert (Tarasov et al., 1998) and suggest that the western Mediterranean borderlands experienced cold climates and enhanced severe aridity (Combourieu Nebout et al., 2002). These changes in vegetation correlate with modifications in marine environments as revealed by coeval modifications of foraminiferal and dinocysts assemblages that mark cooling of the sea surface temperatures (Combourieu Nebout et al., 2002; Sánchez-Goñi et al., 2002). These episodes were immediately followed by increases of temperate pollen assemblage that document rapid warming and fast increasing humidity in the area.

These results are in agreement with the evidence of higher intensity of wind systems over the northern hemisphere during cold intervals (stadials and HE) revealed by the dust content in Greenland ice cores and other results on continents adjacent to the Alboran sea (Mayewski et al., 1997; Sánchez-Goñi et al., 2002; Moreno et al., 2005).

Climatic parameters reconstructed from pollen analyses reveal repetitive oscillations of mean annual precipitation and mean temperature of the coldest month. During the HE, the pollen-based climatic estimates indicates a decrease of at least $200-400 \mathrm{~mm}$ in mean annual precipitation and of $5-15^{\circ} \mathrm{C}$ in mean temperature of the coldest month. The decrease in precipitation is consistent with the elevated abundance of semi-desert taxa. By contrast the reconstructed temperature may appear surprisingly low considering the dominance of Artemisia pollen. At present day, the local species Artemisia herba-alba is usually associated with MTCO of $0-4{ }^{\circ} \mathrm{C}$. More generally, Artemisia is today a major component of steppe ad desert environments. Nevertheless, as pollen grains do not permit the determination at species 
level, it remains difficult to separate hot and warm steppe or desert in the database because of similar associations. This may induce an accentuation of cold temperatures in our samples, but our results remain generally in accordance with other data in marine and continental records (Allen et al., 1999; Sánchez-Goñi et al., 2002). The database is periodically amended in order to solve this problem and better discriminate these two biomes.

When compared to pollen data the variations of some clay minerals appear to vary together with those of temperate, altitudinal and semi-desert groups (Fig. 5). The variations of palygorskite are positively correlated to semi-arid pollen abundances. As a result, palygorskite and precipitation records exhibit a negative correlation index (-0.41). Although their correlation index is low $(\mathrm{r}=0.34)$ chlorite and altitudinal vegetation are somehow linked to each other. By contrast, the kaolinite record appears to be inversely correlated to semi-arid vegetation $(\mathrm{r}=-0.40)$ and to the oxygen isotopic ratio $(\mathrm{r}=-0.40)$. Illite and smectite do not show any significant correlation with pollen data. Principal Component Analysis of this data set indicates a dominant factor $(>80 \%)$ retracing the variations of pollen, palygorskite and $\delta^{18} \mathrm{O}$ of ice from the NorthGRIP ice core whereas the second factor $(<10 \%)$ corresponds to the smectite record.

\section{Discussion}

\subsection{Clay mineral supply}

All clay minerals records show oscillations during the last glacial, but the increase of palygorskite specifically characterizes the North Atlantic cold events whereas the proportions of illite, kaolinite and smectite do not show consistent variations during these climatic events.

The illite and chlorite primarily discharged by the Rhone River can be further transported from the Gulf of Lion to the Alboran Sea by the oceanic gyre (Millot, 1999). This current is characterized by important seasonal variations (Albérola and Millot, 2003). It is more active during winter than in summer when stratification prevents any convective activity (Durrieu de Madron et al., 1999). The chemical composition and morphology of both illite and chlorite indicate proximal sources from, respectively, Betic Cordilleras and NevadoFilaboride complexes (Martínez-Ruiz et al., 1999). Similarly morphological analyses of smectite suggest a soil-derived provenance (Martínez-Ruiz et al., 2003). By contrast, the occurrence of elongated fibers of palygorskite within sediments is characteristic of a wind- 
driven transport. Indeed, there are several evidences that rivers only represent a minor contribution compared to atmosphere at the basin scale (Elbaz-Poulichet et al., 2001),

These results indicate that illite, chlorite and smectite are partly transported via rivers toward the Alboran Sea but may also be supplied through eolian processes together with palygorskite. Clay minerals, except palygorskite, are likely to be transported to the Alboran Sea through oceanic, riverine or eolian processes. As a result their variations are less informative than palygorskite ones in terms of global atmospheric configurations. Nevertheless the increase of some of these clay minerals (i.e. illite during H2, kaolinite during H1) or their decrease (i.e. smectite during H3, kaolinite during H2) suggests that regional specific configurations are likely to modify the clay mineral association.

\subsection{Provenance of palygorskite}

The presence of palygorskite (Fig. 4e) and the increase in semi-desert taxa (Fig. 5a and b) characterizing sediments deposited during the cold intervals confirm that arid conditions prevailed on the continent during the North Atlantic cold climatic events (Cacho et al. 2000; Combourieu Nebout et al., 2002; Moreno et al., 2002; Sánchez-Goñi et al., 2002).

Because palygorskite is typical of arid and semi-arid climate, it mainly records the North African contribution to sedimentation. Palygorskite is also reported in several formations over the Iberian Peninsula. Although such proximal supply from the Iberian Peninsula has to be taken in account, it is not a major contributor to Alboran deep-sea sedimentation since (1) palygorskite is easily destroyed while transported by rivers and (2) only trace amounts of palygorskite have been detected in proximal sediments. Western Morocco, northern Algeria, central Algeria and southern Sahara (Paquet et al., 1984; El Mouden et al., 2005), as well as reworked Neogene North African deposits (e.g. Chamley, 1989), are potential palygorskite source areas.

In order to pinpoint its origin, the palygorskite content was compared with the illite-tokaolinite (I/K) ratio (Fig. 6) which remains unchanged after long-term transport (Caquineau et al., 1998). This comparison gives a rough estimation of the respective contribution of eolian vs. riverine supplies. The $\mathrm{I} / \mathrm{K}$ ratio (Fig. 6) is also a relevant fingerprint of the regional origin of Saharan dust (Caquineau et al., 1998): dust from North and West Sahara is enriched in illite $(\mathrm{I} / \mathrm{K}=2)$ whereas kaolinite $(\mathrm{I} / \mathrm{K}=0.1)$ becomes dominant when the dust has a Sahelian origin (Paquet et al., 1984). South and central Sahara are characterized by intermediate values 
$453(\mathrm{I} / \mathrm{K}=0.4)$ (Caquineau et al., 1998). This latitudinal evolution is consistent with the 454 mineralogy of Atlantic sediments and dust collected over the Atlantic Ocean (e.g. Chamley, 455 1989). The content in kaolinite of dust also varies with the longitude. The $\mathrm{I} / \mathrm{K}$ ratio decreases 456 from the northwestern Africa ( $\mathrm{I} / \mathrm{K}=2-1.1$ in northern Algeria) to northeastern Africa (I/K $457=0.5-0.7$ ) (e.g. Guerzoni and Chester, 1996; Caquineau et al., 1998). In the studied samples 458 the $\mathrm{I} / \mathrm{K}$ ratio ranges from 1.35 to 3 with an average value of 2.1 , and does not significantly 459 change during the old events (Fig. 6). Our data indicate that the eolian contribution should be 460 important in the Alboran Sea since the $\mathrm{I} / \mathrm{K}$ ratio of proximal riverine supply is rather low (I/ K $461=1.38$ ) (Alonso and Maldonado, 1990). When compared with data from Caquineau et al. 462 (1998) this ratio suggests sources from the North and West Sahara (I/ K =1.3-2.6) and rules 463 out any contribution from Sahel (I/ Ko0.25) or South and central Sahara ( $/ \mathrm{K}=0.4-0.7)$. 464 During the North Atlantic cold events, the $\mathrm{I} / \mathrm{K}$ remains stable while the palygorskite content 465 increases. This result indicates larger contribution of an eolian source characterized by a high 466 palygorskite content and I/K ratio around 2, such as western Morocco (El Mouden et al., 467 2005). Furthermore, the presence of Argania pollen, typical of southern Morocco, associated 468 with the palygorskite within the HE, HE1 and HE4, supports the southern origin of dust. The presence of Argania pollen suggests low precipitation (200-400 mm) and positive temperatures. This result is not contradictory with the reconstructed MTCO because this pollen was not used in the MAT modeling and because the occurrence of Argania is here interpreted as an evidence of intense eolian transport from southern areas during these HE. Argania pollen were probably transported together with palygorskite from southern areas which were not so cold but arid. The sediments from the ODP 976 seem to result from the mixing between riverine supply (possibly the Ebro River) and eolian contributions from

\subsection{Palygorskite transport—atmospheric configuration}

As palygorskite represents the eolian contribution to deep-sea sedimentation, its abundance suggests that the continental aridity was associated with specific atmospheric configurations favoring dust transport from the source area to the Alboran sea. The different atmospheric scenario leading to palygorskite-rich dust transport issued from Sahara toward 483 Europe are described by specific air-masses trajectories. Several studies (e.g. Avila et al., 484 1997; Rodríguez et al., 2001), based on decennial observations, attempt to reconstruct the main trajectories of dust outbreaks reaching Europe and their associated atmospheric 
configurations (Fig. 7). These dust events are clearly controlled by the intensity of the westerly winds regime over Europe. The migration of both anticyclone and depression cells over the tropical Atlantic, the Mediterranean, the European and North African continents seasonally modulates these situations. According to the potential sources of palygorskite and to the regional wind system, the potential atmospheric configuration resulting in enhanced palygorskite supply during the North Atlantic cold events can then be discussed (Fig. 7).

During summer the thermal convective activity over central and southern Sahara desert lifts dust particles to high atmosphere (Prospero, 1981a, b). This Saharan air mass flows westward at high-altitude. A part of this air mass is further redistributed over longrange distance toward the Mediterranean (pathway 4) by the northern branch of the SAL (Prospero, 1981a, b). This scenario would favor an increased contribution of dust originating from the Lake Chad area. But even if the Bodéle depression is considered to be one of the main dust sources at present-day, there is so far no clear evidence of palygorskite occurrence in dust originating from this area. But few mineralogical studies have attempted to identify fibrous clays so far. The average level of the Lake Chad has dropped during the late Holocene while dustiness increases continuously. These conditions are likely to favor an enhanced production and export of palygorskite toward the Mediterranean if considering Lake Chad as a potential source area. According to our data, there is no significant increase in palygorskite input in the Alboran Sea during the Holocene. The clay mineral fraction composition remains stable over the Holocene. This observation suggests that the Bodélé depression and Lake Chad were probably not the main sources of dust during the North Atlantic cold climatic events.

In the lower trades, below the SAL $(850 \mathrm{hPa}, 1500 \mathrm{~m})$ the northward transport of desert dust (Fig. 2b) is also seasonally modulated (Bergametti et al., 1989a; Chiapello et al., 1995; Guerzoni et al., 1997; Moulin et al., 1997; Rodríguez et al., 2001). During summer the remoteness of the Azores high and the displacement of the North African anticyclone over Algeria favor the incursion of a depression trench between these two anticyclones gyres (Coudé- Gaussen, 1982; Bergametti et al., 1989a; Moulin et al., 1997; Rodríguez et al., 2001; Torres-Padrón et al., 2002). Dust particles originating from western and central part of the Sahara (Guerzoni et al., 1997) are transported toward the western and central part of the Mediterranean (Figs. 2c and 7, pathway 3) (Moulin et al., 1997). The atmospheric backtrajectories associated with such events indicate that the main dust emission is located in the western part of Morocco, where important source of palygorskite have been identified (Avila 
et al., 1997; El Mouden et al., 2005). The increase of palygorskite associated with the North Atlantic cold events could then be tentatively attributed to dominant summer atmospheric configurations. Such meridian circulation of air masses occurs when the westerly regime is weak or disrupted (Coudé-Gaussen, 1982). It would then imply that the North Atlantic cold climatic events are associated with a reduction or a northward shift of the westerlies over Europe. Our results confirm the previous studies in the Alboran sea sediments suggesting a link between the North Atlantic cold events (stadials and HE) and the westerly regime over Europe (Cacho et al., 2000; Combourieu Nebout et al., 2002; Moreno et al., 2002; SánchezGoñi et al., 2002)

In winter (Figs. 2b and 7) African dust outbreaks mainly reach Europe through meridian circulation across the Mediterranean (Coudé-Gaussen, 1982). A NS depression trench (Fig. 7) is created between the Azores high (pathway 1) and the high-pressure located over central Mediterranean or over North Africa (Rodríguez et al., 2001; Torres- Padrón et al., 2002). Saharan air masses move northward along the western edge of the high-pressure cell (Coudé- Gaussen, 1982; Rodríguez et al., 2001). The trajectory of such meridian transport is constrained both by the position and the high-pressure cell and the Atlas Mountains (Fig. 7), mainly providing dust and pollen to the northwestern and central Mediterranean. A recent study of southern Europe sedimentary records suggest that this pattern is responsible for the presence of Cedrus pollen originating from northwest Africa and flowering in winter (Magri and Parra, 2002). But the reconstructed trajectories indicate that dust particles were not able to reach the Alboran Sea. This eastern pattern is not likely to influence significantly the sedimentation in the Alboran Sea.

Inter-season Saharan dust outbreaks represent less than $30 \%$ of the total dust emission (Guerzoni et al., 1997; Rodríguez et al., 2001). Spring and early summer dust events represent $20 \%$ of total annual events (Rodríguez et al., 2001). They are linked to the position of cyclones which favors the air masses crossing the Mediterranean between Tunisia and Egypt toward eastern and central Mediterranean basins (Moulin et al., 1997). Such wind trajectories would not be able to transport fine-dust particles toward the Alboran Sea. At the end of summer the dust main routes are shifted westward because most cyclones originate from the

548 Balearic region. The dust outbreaks have a general NE trajectory toward Corsica and Italy (Bergametti et al., 1989c) (Fig. 7, pathway 1b). Nevertheless the presence of the Atlas mountain (Fig. 7) shift to the East the main direction of dominant winds, preventing any significant contribution to the Alboran Sea sedimentation. 
Saharan intrusions occurring during fall represent less than $10 \%$ of the total annual events (Rodríguez et al., 2001). These events are generally induced by the simultaneous occurrence of a depression off the southwest Iberian Peninsula and of a high-pressure cell over Algeria (Fig. 7, pathway 2) (Rodríguez et al., 2001). The dominant direction of associated winds is likely to transport Saharan dust to the Iberian Peninsula and to the Alboran Sea. Moreover, the dust produced by this synoptic situation probably originates from one of the potential source area of palygorskite (Paquet et al., 1984). But the rare occurrence of such events and their low contribution to the annual dust export suggest they are not the main mechanism leading to palygorskite input in the Alboran Sea. But synoptic situations were different during the last glacial. The enhanced supply associated with the North Atlantic cold events may then indicate that the modern meteorological situation leading to fall Saharan intrusions was much more frequent than today.

In summary, according to the provenance of palygorskite and to the atmospheric backtrajectories, the pathways 2 and 3 are the most probable patterns followed by western Moroccan dust-blown particles which characterize the North Atlantic cold events.

\subsection{Paleoclimatic implications}

Glacial periods are characterized by dust fluxes 1.5 to 6 times higher than today especially in tropical oceans (Kolla et al., 1979; Chamley et al., 1989; Ruddiman, 1997; Hoogakker et al., 2004). This enhanced supply was attributed to an aridification of the continents (Kolla et al., 1979; Rea, 1994) and/or to strengthening of the winds (Ruddiman, 1997). During glacial intervals, cold and dry conditions develop over the Mediterranean as a result of colder sea surface temperatures associated with the stability of the northern highpressure cell and with an increased seasonality of precipitations (Prentice et al., 1992; PérezFolgado et al., 2003). There is a strong relationship between rainfall and dust storm occurrence (Middleton, 1985). Low precipitations limit the expansion of vegetation, favoring the erosion of unconsolidated fine-grained soil particles (Middleton, 1985; Balsam et al., 1995). As a consequence the aridification is thought to become one of the main factor controlling the production of dust during glacial periods (Kolla et al., 1979; Middleton, 1985; Rea, 1994). But other studies evidenced the influence of wind intensity on the enhanced glacial dust fluxes. Previous studies mainly based on pollen and sediment analyses suggest the intensification of winds, favoring the northward transport of dust across the Mediterranean during the last glacial period. This enhanced eolian input from North Africa was evidenced in 
lacustrine sediments from central Italy (Narcisi, 2000) and in terrestrial deposits from a

586 Mediterranean island (Lampedusa) located between Tunisia and Sicily (Giraudi, 2004). The presence of Cedrus pollen, a modern maker of northwest African provenance, in several sites from southern Europe, also supports this hypothesis (Magri and Parra, 2002). Several studies argued that winter transport over the Atlantic ocean should be enhanced during glacial

590

591 because the most intense present-day dust events originating from the southern Sahelian region typically occur during winter (Chiapello et al., 1997; Ratmeyer et al., 1999; Hoogakker et al., 2004; Washington and Todd, 2005). But major dust outbreaks originating from West and North Sahara also occur during summer (Moulin et al., 1997; Rodríguez et al., 2001; Ginoux et al., 2004). This mechanism should be considered to explain the increased dust fluxes during glacial (Balsam et al., 1995). Grousset et al. (1998) then suggested that both aridity and wind strength should be involved to explain the high glacial dust input. In the frame of the recent studies in the Alboran Sea, our results allow to highlight the importance of eolian processes during the North Atlantic cold events.

In West Mediterranean, cold events as HE and Dansgaard/Oeschger stadials are evidenced by the increase of deep oceanic convection and by the development of arid and cold conditions on the surrounding continents. Locally these cold events seem to be related to changes in atmospheric circulation and intensification of westerly winds (Rohling et al., 1998; Sánchez-Goñi et al., 2002). The increase of steppic plants in Alboran sea sediments associated with low paleoprecipitation estimations indicates that HE were dry and cold (Combourieu Nebout et al., 2002; Sánchez-Goñi et al., 2002). Such a decrease has already been observed in other records in Alboran Sea and off Portugal for HE 3 to 5 (Sánchez-Goñi et al., 2002) and in continental series in Lago Grande di Monticchio, Italy (Allen et al., 1999). It remains slightly higher than the sea surface temperature changes $\left(5-10^{\circ} \mathrm{C}\right)$ obtained from alkenones in the Alboran Sea (Cacho et al., 2000) and the temperature of the coldest month deduced from the Monticchio record for the studied period (Allen et al., 1999). As already mentioned in Section 4.2, the small discrepancies between the MTCO at site ODP 976 (Alboran sea) and in Monticchio record may result both from the use of different methods of reconstruction and database. High eolian fluxes based on grain-size measurements, resulting from increased aridity and wind strength, were also evidenced in the Alboran Sea sediments during H3, H4 and H5 (Moreno et al., 2002). Our data also suggest that aridity was enhanced during the North Atlantic cold events, as revealed by steppic vegetation, precipitation estimation and clay minerals (Fig. 5). The presence of palygorskite indicates that peri-Mediterranean areas 
were dry with sparse vegetation cover, allowing the erosion of unconsolidated soils. As palygorskite is wind transported, its increase suggests a significant wind strengthening over northern North Africa and allows the reconstruction of the dominant synoptic conditions over the Mediterranean during the North Atlantic cold events. The meridian transport of palygorskite to the Alboran Sea during the North Atlantic cold events implies not only that strong high-pressure cells develop over the tropical Atlantic (Azores High) and over the North African continent (North African High) but also that the westerlies, probably shifted northward, would not prevent the incursion of the Saharan masses toward Europe.

\subsection{Relation with the $N A O$}

According to the identification of the main clay sources and to atmospheric back trajectories, the increase of palygorskite during the North Atlantic cold events indicates the stability of two high-pressure cells, the Azores high over the tropical Atlantic Ocean and the North African anticyclone over Algeria. During the North Atlantic cold climatic events, these two high-pressure systems were associated with the existence of a depression over western Europe. The meridian transport of the palygorskite implies that the westerly regime was weak, disrupted or displaced northward. Such synoptic situations are very similar with positive phases of the so-called NAO (Hurrell, 1995). Moulin et al. (1997) evidenced the role of the NAO in controlling the desert dust transport. The NAO is responsible for much of the climate variability observed in the Mediterranean region (Fig. 8) at present-day and possibly during the last glacial (Cacho et al., 2000; Combourieu Nebout et al., 2002; Moreno et al., 2002; Sánchez-Goñi et al., 2002). During positive phase of the NAO, the high-pressure gradient between the strong Azores anticyclone and the Icelandic depression results in a northward shift and an increase strength of the westerlies (Hurrell, 1995). When the NAO is high, dry conditions develop over southern Europe and North Africa (Pittalwala and Hameed, 1991) and the northeast trade winds intensity increases, leading to the enhanced westward transport of desert dust (Moulin et al., 1997). As a result, severe decennial time-scale droughts in Sahel are correlated to low surface temperature in the North Atlantic Ocean (Moulin et al., 1997). Conversely, when the NAO is negative, the pressure gradient between the Azores high and the Iceland low decreases (Hurrell, 1995). The westerlies are shifted to the South providing precipitations over the Mediterranean and the North African continent. Negative phases of the NAO thus prevent dust uptake and transport (Moulin et al., 1997). Several studies in the West Mediterranean and in the Alboran Sea highlight the influence of 
northwesterly and Saharan winds in the low sea surface temperatures, in high continental aridity, and in the enhanced dust transport associated with the $\mathrm{HE}$ and $\mathrm{D} / \mathrm{O}$ stadials.

The modification of the northwesterly regime was compared to the present-day NAO (Cacho et al., 2000; Combourieu Nebout et al., 2002; Moreno et al., 2002, 2005; SánchezGoñi et al., 2002), but oscillating with a lower frequency than the decennial one (Hurrell, 1995). High NAO index and increased intensity of the northwesterlies were also invoked to explain the active deep-water convection which occurs in the Mediterranean during HE and stadials (Rohling et al., 1998; Cacho et al., 2000). Furthermore, modeling data indicate high correlation between the winter NAO index and the dust emission from the Bodélé regionLake Chad area. But this model does not take in account the impact of vegetation reduction on the erodability of soils. Moreover, since no palygorskite was reported so far in dust-blown particles from the Bodélé region, this area cannot be considered as the main dust contributor toward the Alboran sea during the North Atlantic cold events. Our results suggest that palygorskite-rich events are favored by specific atmospheric configurations. A depression corridor is created between the Azores high and the North African anticyclone, leading to the transport of dust particles from western Morocco to the Alboran Sea. Such meridian transfer is efficient only if westerlies are weak, disrupted or displaced northward. But recent studies suggest that the northwesterlies were intense during D/O stadials (Rohling et al., 1998; Cacho et al., 2000; Moreno et al., 2002; Sánchez-Goñi et al., 2002). Our data indicate that northwesterlies should be shifted to the North during the North Atlantic cold events in order to allow the intrusion of Saharan air masses toward Europe. This interpretation is not contradictory with previous studies suggesting intensification of the westerly winds, but may explain the singular feature of the amplified aridity signal characterizing the HE compared to other $\mathrm{D} / \mathrm{O}$ stadials by shifting the westerly winds toward a more northerly position (Combourieu Nebout et al., 2002; Sánchez-Goñi et al., 2002).

\section{Conclusions}

The Alboran core ODP 976 provides a combined mineralogical and palynological data set that illustrates connection between climatic and atmospheric system on West Mediterranean throughout the last glacial cycle. Our results provide new insights on the atmospheric configuration in the Alboran Sea during last glacial, especially during the North Atlantic cold events. 
The increase of palygorskite - a typical wind-blown clay mineral—-during these cold

684

685

686

687

688

689

690

691

692

693

694

695

696

697

698

699

700

701

702

703

704

705

706

707

708

709

710

\section{1}

712

713

714 episodes suggests the intensification of dust events across the Mediterranean during the North Atlantic cold events. The peculiar mineralogical composition of the clay-size fraction evidences western Morocco as a potential source of dust during the North Atlantic cold events. This hypothesis is supported by the abundance of semi-desert taxa and the presence of Argania pollen associated with palygorskite. Coeval palygorskite supply and development of the semi-arid vegetation during the North Atlantic cold events suggest severe droughts on peri-Mediterranean areas, as evidenced by estimated annual precipitations. The enhanced Saharan dust export toward the Alboran Sea during the North Atlantic cold events also implies a strengthening of dominant winds. According to the different air mass trajectories resulting from various atmospheric configurations, summer-type dust events are the best candidate to explain the important transport of fine-particles from western Morocco to the Alboran Sea. According to atmospheric models, such a meridian transport (1) results from the development of strong and stable anticyclonic conditions over the tropical Atlantic and North Africa, similar to today's summer meteorological configuration and (2) implies a northward position of the westerly winds during the North Atlantic cold events.

The reconstructed synoptic situation over the West Mediterranean during the North Atlantic cold events was compared with meteorological configurations characterizing the NAO. This observation reveals that the prevailing weather regime over North Africa and western Europe during the North Atlantic cold events was very similar to the one described for positive phases of the NAO, suggesting a systematic shift towards a positive NAO situation.

Further geochemical analyses will help to estimate the contribution of the Moroccan source versus other sources such as the Bodélé region during the North Atlantic cold events. Moreover high-resolution mineralogical and palynological studies of sediments deposited during the Marine Isotopic Stage 5 and the Holocene in the Alboran sea will give essential informations on the links between North Atlantic climate and Mediterranean weather regimes.

\section{Acknowledgments}

We thank the Ocean Drilling Program for making the samples available for that study. We acknowledge J.P. Cazet for his efficient technical assistance. French scientists received financial support from CNRS, from Lille 1 University and from French Program National 
715 d'Etude de la Dynamique du Climat (PNEDC). We express our gratitude to Aloys Bory for 716 critical reading of the manuscript. The authors thank F. Grousset and D. Magri for their useful 717 critical reviews. This is Laboratoire des Sciences du Climat et l'Environnement contribution 718 no. 2801.

\section{References}

721 Albérola, C., Millot, C., 2003. Circulation in the French Mediterranean coastal zone near 722 Marseille: influence of the wind and of the northern current. Continental Shelf Research 23, $723587-610$.

724 Allen, J.R.M., Brandt, U., Brauer, A., Hubberten, H.-W., Huntley, B., Keller, J., Kraml, M., 725 Mackensen, A., Mingram, J., Negendank, J.F.W., Nowaczyk, N.R., Oberhänsli, H., Watts, 726 W.A., Wulf, S., Zolitschka, B., 1999. Rapid environmental changes in southern Europe 727 during the last glacial period. Nature 400, 740-743.

728 Alonso, B., Maldonado, A., 1990. Late Quaternary sedimentation patterns of the Ebro 729 turbidite systems (northwestern Mediterranean): two styles of deep-sea deposition. Marine 730 Geology 95, 353-377.

731 Avila, A., Queralt-Mitjans, I., Alarcón, M., 1997. Mineralogical composition of African dust 732 delivered by red rains over northeastern Spain. Journal of Geophysical Research 102 (18), $73321,977-21,996$.

734 Balsam, W.L., Otto-Bliesner, B.L., Deaton, B.C., 1995. Modern and last glacial maximum 735 eolian sedimentation patterns in the Atlantic Ocean interpreted from sediment iron oxide content. Paleoceanography 10, 493-507.

737 Bergametti, G., Dutot, A.L., Buat-Menard, P., Losno, R., Remoudaki, E., 1989a. Seasonal 738 variability of the elemental composition of atmospheric aerosol particles over the 739 northwestern Mediterranean. Tellus 41 (B), 353-361.

740 Bergametti, G., Gomes, L., Coudé-Gaussen, G., Rognon, P., Le Coustumer, M.N., 1989b. 741 African dust observed over Canary islands: source-regions identification and transport pattern 742 for some summer situations. Journal of Geophysical Research 94, 14855-14864.

743 Bergametti, G., Gomes, L., Remoudaki, E., Desbois, M., Martin, D., Buat-Menard, P., 1989c. 744 Present transport and deposition patterns of African dusts to the North-Western 745 Mediterranean. In: Leinen, M., Sarnthein, M. (Eds.), Paleoclimatology and Paleometeorology: 
Modern and Past Patterns of Global Atmospheric Transport. Serie C/ Mathematical and

747 Physical Sciences. Kluwer Academic, Dordrecht, pp. 227-251.

748 Béthoux, J.P., 1980. Mean water flux across sections in the Mediterranean sea, evaluated on the basis of water and salt budgets and of observed salinities. Oceanologica Acta. 3, 79-88.

750 Brindley, G.W., Brown, G., 1980. Crystal Structures of Clay Minerals and their X-ray 751 Identification. Mineralogical Society, London.

752 Brooks, N., Legrand, M., 2000. Dust variability over northern Africa and rainfall in the Sahel. 753 In: McLaren, S.J., Kniveton, D. (Eds.), Linking Climate Change to Land surface Change. 754 Kluwer Academic, Dordrecht, pp. 1-25.

755 Cacho, I., Grimalt, J.O., Sierro, F.J., Shackleton, N., Canals, M., 2000. Evidence for enhanced 756 Mediterranean thermohaline circulation during climatic coolings. Earth and Planetary Science 757 Letters 183, 417-429.

758 Caquineau, S., Gaudichet, A., Gomes, L., Magonthier, M.-C., Chatenet, B., 1998. Saharan 759 dust: clay ratio as a relevant tracer to assess the origin of soil-derived aerosols. Geophysical 760 Research Letters 25, 983-986.

761 Chamley, H., 1989. Clay Sedimentology. Springer, Berlin.

762 Chamley, H., Debrabant, P., Robert, C., Mascle, G., Rehault, J.P. Aprahamian, J., 1989. 763 Mineralogical and geochemical investigations on latest Miocene deposits in the Tyrrhenian 764 sea (ODP Leg 107). In: Kastens, K., Mascle, J., et al., (Eds.), Ocean Drilling Program, 765 Proceedings 107B. US Government Printing Office, pp. 1501-1513.

766 Chiapello, I., Bergametti, G., Gomes, L., Chatenet, B., Dulac, F., Pimenta, J., Santo Suares, 767 E., 1995. An additional low layer transport of Sahelian and Saharan dust transport over the 768 north-eastern tropical Atlantic. Geophysical Research Letters 22, 3191-3194.

769 Chiapello, I., Bergametti, G., Chatenet, B., Bousquet, P., Dulac, F., Santos Suarez, E., 1997. 770 Origins of African dust transported over the north-eastern tropical Atlantic. Journal of 771 Geophysical Research 102 (D12), 13701-13709.

772 Combourieu Nebout, N., Turon, J.L., Zahn, R., Capotondi, L., Londeix, L., Pahnke, K., 2002. 773 Enhanced aridity and atmospheric high-pressure stability over the western Mediterranean 774 during the North Atlantic cold events of the past 50 ky. Geology 30 (10), 863-866. 
775 Coudé-Gaussen, 1982. Les poussières éoliennes sahariennes. Mise au point. Revue de

776 Géomorphologie Dynamique 31, 49-69.

777 Coudé-Gaussen and Blanc, M 1985. Présence de grains éolisés de palygorskite dans les

778

779

780

781

782

783

784

785

786

787

788

789

790

791

792

793

794

795

796

797

798

799

800

801

802

803

804 2002. Distributions of $\mathrm{Pu}, \mathrm{Am}$ and $\mathrm{Cs}$ in margin sediments from the western Mediterranean 805 (Spanish coast). Journal of Environmental Radioactiviy 59, 75-89. poussières actuelles et les sédiments d'origine désertique. Bulletin de la SociétéGéologique de France 8 (1), 571-579.

Coudé-Gaussen, G., Hillaire-Marcel, C., Rognon, P., 1982. Origine et évolution pédologique des fractions carbonatées dans les loess des Matmata (Sud-Tunisien) d'après leurs teneurs en 13C et 18O. Comptes Rendus de l'Académie des Sciences de Paris 295, 939-942.

Coudé-Gaussen, G., Rognon, P., Bergametti, G., Gomes, L., Strauss, B., Le Coustumer, M.N., 1987. Saharan dust on Fuerteventura island (Canaries): chemical and mineralogical characteristics, air mass trajectories, and probable sources. Journal of Geophysical Research 92, 9753-9771.

Desprat, S., Sánchez-Goñi, M.F., Turon, J.-L., McManus, J., Loutre, M.F., Duprat, J., Malaizé, B., Peyron, O., Peypouquet, J.-P., 2005. Is vegetation responsible for glacial inception during periods of muted insolation changes? Quaternary Science Reviews 24 (1213), 1361-1375.

Durrieu de Madron, X., Radakovitch, O., Heussner, S., Loÿe-Pilot, M.- D., Monaco, A., 1999. Role of the climatological and current variability on shelf-slope exchanges of particulate matter: evidence from the Rho^ ne continental margin (NW Mediterranean). Deep-Sea Research I 46, 1513-1538.

El Mouden, A., Bouchaou, L., Snoussi, M., 2005. Constraints on alluvial clay mineral assemblages in semiarid regions. The Souss Wadi Basin (Morocco, Northwestern Africa). Geologica Acta 3 (1), 3-13.

Elbaz-Poulichet, F., Guieu, C., Morley, N.H., 2001. A reassessment of trace metal budgets in the western Mediterranean sea. Marine Pollution Bulletin 42 (8), 623-627.

Foucault, A., Mélières, F., 2000. Palaeoclimatic cyclicity in central mediterranean Pliocene sediments: the mineralogical signal. Palaeogeography, Palaeoclimatology, Palaeoecology $158,311-323$.

Gascó, C., Antón, M.P., Pozuelo, M., Meral, J., González, A.M., Papucci, C., Delfanti, R., 
806 Ginoux, P., Prospero, J.M., Torres, O., Chin, M., 2004. Long-term simulation of global dust 807 distribution with the GOCART model: correlation with North Atlantic Oscillation. 808 Environmental Modelling and Software 19, 113-128.

809 Giraudi, C., 2004. The upper Pleistocene to Holocene sediments on the Mediterranean island 810 of Lampedusa (Italy). Journal of Quaternary Science 19, 537-545.

811 Grousset, F.E., Rognon, P., Coudé-Gaussen, G., Pédemay, P., 1992. Origins of peri-Saharan 812 dust deposits traced by their $\mathrm{Nd}$ and $\mathrm{Sr}$ isotopic composition. Palaeogeography, 813 Palaeoclimatology, Palaeoecology

814 Grousset, F.E., Parra, M., Bory, A., Martinez, P., Bertrand, P., Shimmield, G., Ellam, R.M., 815 1998. Saharan wind regimes traced by the $\mathrm{Sr}-\mathrm{Nd}$ isotopic composition of subtropical Atlantic 816 sediments: last glacial maximum vs. today. Quaternary Science Reviews 17, 385-409.

817 Guerzoni, S., Chester, R., 1996. The Impact of Desert Dust Across the Mediterranean. Kluwer 818 Academic, Dordrecht.

819 Guerzoni, S., Molinaroli, E., Chester, R., 1997. Saharan dust inputs to the western 820 Mediterranean sea: depositional patterns, geochemistry and sedimentological implications. 821 Deep-Sea Research II 44 (3-4), 631-654.

822 Guerzoni, S., Chester, R., Dulac, F., Herut, B., Loÿe-Pilot, M.-D., Measures, C., Migon, C., 823 Molinaroli, E., Moulin, C., Rossini, P., Saydam, C., Soudine, A., Ziveri, P., 1999. The role of 824 atmospheric deposition in the biogeochemistry of the Mediterranean sea. Progress in 825 Oceanography 44, 147-190.

826 Guiot, J., 1990. Methodology of the last climatic cycle reconstruction in France from pollen 827 data. Palaeogeography, Palaeoclimatology, Palaeoecology 80, 49-69.

828 Hoogakker, B.A.A., Rothwell, R.G., Rohling, E.J., Paterne, M., Stow, D.A.V., Herrle, J.O., 829 Clayton, T., 2004. Variations in terrigenous dilution in western Mediterranean sea pelagic 830 sediments in response to climate change during the last glacial cycle. Marine Geology 211, $83121-43$.

832 Hurrell, J.W., 1995. Decadal trend in the North Atlantic Oscillation: regional temperatures 833 and precipitations. Science 269, 676-679.

834 Johnsen, S., Clausen, H.B., Dansgaard, W., Fuhrer, K., Gundestrup, M., Hammer, C.U., 835 Iversen, P., Jouzel, J., Stauffer, B., Steffensen, J.P., 1992. Irregular glacial interstadials 836 recorded in a new Greenland ice core. Nature 359, 311-313. 
837 Kolla, V., Biscaye, P.E., Hanley, A.F., 1979. Distribution of quartz in late Quaternary

838 Atlantic sediments in relation to climate. Quaternary Research 11, 261-277.

839 Loye-Pilot, M.-D., Martin, J.-M., Morelli, J., 1986. Influence of Saharan dust on the rainfall 840 acidity and atmospheric input to the Mediterranean. Nature 321, 427-428.

841 Luck, J.M., Ben Othman, D., 2002. Trace element and Pb isotope variability during rainy 842 events in the NW Mediterranean: constraints on anthropogenic and natural sources. Chemical 843 Geology 182, 443-460.

844 Magri, D., Parra, I., 2002. Late Quaternary western Mediterranean pollen records and African 845 winds. Earth and Planetary Science Letters 200, 401-408.

846 Martínez-Ruiz, F., Comas, M.C., Alonso, B., 1999. Mineral associations and geochemical 847 indicators in upper Miocene to Pleistocene sediments in the Alboran basin (ODP leg 161, 848 Sites 976 and 977). In: Zahn, R., Comas, M.C., Klaus, A. (Eds.), Proceedings of the Ocean 849 Drilling Program, Scientific Results. College Station, TX, pp. 21-36.

850 Martínez-Ruiz, F., Paytan, A., Kastner, M., González-Donoso, J.M., Linares, D., Bernasconi, 851 S.M., Jimenez-Espejo, F.J., 2003. A comparative study of the geochemical and mineralogical 852 characteristics of the S1 sapropel in the western and eastern Mediterranean. Palaeogeography, 853 Palaeoclimatology, Palaeoecology 190, 23-37.

854 Masson-Delmotte, V., Landais, A., Combourieu-Nebout, N., von Grafenstein, U., Jouzel, J., 855 Caillon, N., Chappellaz, J., Dahl-Jensen, D., Johnsen, S., Stenni, B., 2005. Rapid climate 856 variability during warm and cold periods in polar regions and Europe. C.R. Geosciences $857337,935-946$.

858 Matthewson, A.P., Shimmield, G., Kroon, D., Fallick, A.E., 1995. A 300 kyr high-resolution 859 aridity record of the north African continent. Paleoceanography 10, 677-692.

860 Mayewski, P.A., Meeker, L.D., Twickler, M.S., Whitlow, S., Yang, Q., Lyons, W.B., 861 Prentice, M., 1997. Major features and forcing of high latitude northern hemisphere 862 atmospheric circulation using a 110,000- year-long glaciochemical series. Journal of 863 Geophysical Research 102, 23,366-26,345.

864 Middleton, N.J., 1985. Effect of drought on dust production in the Sahel. Nature 316, 431865434. 
866 Milliman, J.D., Meade, R.H., 1983. World-wide delivery of river sediment to the oceans. 867 Journal of Geology 91, 1-21.

868 Millot, C., 1999. Circulation in the western Mediterranean Sea. Journal of Marine Systems $86920,423-442$.

870 Molinaroli, E., 1996. Mineralogical characterization of Saharan dust with a view to its final 871 destination in Mediterranean sediments. In: Guerzoni, S., Chester, R. (Eds.), The Impact of 872 Desert Dust across the Mediterranean. Kluwer Academic, Dordrecht, pp. 153-162.

873 Moreno, A., Cacho, I., Canals, M., Prins, M.A., Sánchez-Goñi, M.F., Grimalt, J.O., Weltje, 874 G.J., 2002. Saharan dust transport and high latitude glacial climatic variability: the Alboran 875 sea record. Quaternary Research 58, 318-328.

876 Moreno, A., Cacho, I., Canals, M., Grimalt, J.O., Sánchez-Goñi, M.F., Shackleton, N., Sierro, 877 F.J., 2005. Links between marine and atmospheric processes oscillating on a millennial time878 scale. A multiproxy study of the last 50,000 yr from the Alboran sea. Quaternary Science 879 Reviews 24, 1623-1636.

880 Moulin, C., Lambert, C.E., Dulac, F., Dayan, U., 1997. Control of atmospheric export of dust 881 from north Africa by the north Atlantic Oscillation. Nature 387, 691-694.

882 Narcisi, B., 2000. Late Quaternary eolian deposition in central Italy. Quaternary Research 54, $883246-252$.

884 NorthGRIP members, 2004. High resolution climate record of the northern hemisphere back 885 to the last interglacial period. Nature 431, 147-151.

886 Ozenda, P., 1975. Sur les étages de végétation dans les montagnes du bassin Méditerranéen. 887 Documents de Cartographie Ecologique 16, 1-32.

888 Paquet, H., Coudé-Gaussen, G., Rognon, P., 1984. Etude minéralogique de poussières 889 sahariennes le long d'un itinéraire entre $19^{\circ}$ et $35^{\circ}$ de latitude nord. Revue de Géologie 890 Dynamique et de Géographie Physique 25, 257-265.

891 Pastouret, L., Chamley, H., Delibrias, G., Duplessy, J.C., Thiede, J., 1978. Late Quaternary 892 climatic changes in western tropical Africa deduced from deep-sea sedimentation of the Niger 893 delta. Oceanologica Acta 1 (2), 217-232.

894 Pérez-Folgado, M., Sierro, F.J., Flores, J.A., Cacho, I., Grimalt, J.O., 
895

896

897

898

899

900

901

902

903

904

905

906

907

908

909

910

911

912

913

914

915

916

917

918

919

920

921

922

923

924

Zahn, R., Shackleton, N., 2003. Western Mediterranean planktonic foraminifera events and millennial climatic variability during the last 70 kyr. Marine Micropaleontology 48, 49-70.

Petschick, 2000. MacDiff Freeware.

Peyron, O., Guiot, J., Cheddadi, R., Tarasov, P., Reille, M., de Beaulieu, J.-L., Bottema, S., Andrieu, V., 1998. Climatic reconstruction in Europe for 18,000 yr BP from pollen data. Quaternary Research 49, 183-196.

Pittalwala, I., Hameed, I., 1991. Simulation of the North Atlantic Oscillation in a general circulation model. Geophysical Research Letters 18, 841-844.

Prentice, I.C., Cramer, W., Harrison, S.P., Leemans, R., Monserud, R.A., Solomon, A.M., 1992. A global biome model based on plant physiology and dominance, soil properties and climate. Journal of Biogeography 19 (2), 117-134.

Prospero, 1981b. Arid regions as sources of minerals aerosols in the marine atmosphere. Geological Society of America, Special paper 186, 71-86.

Prospero, 1981b. Eolian transport to the world ocean. In: Emiliani, C. (Ed.), The Sea VII the Oceanic Lithosphere. Wiley, New York, pp. 871-874.

Prospero, J.M., Glacuum, R.A., Nees, R.T., 1981. Atmospheric transport of soil dust from Africa to South America. Nature 289, 570-572.

Pye, K., 1987. Aeolian Dust and Dust Deposits. Academic Press, San Diego, USA.

Ratmeyer, V., Fischer, G., Wefer, G., 1999. Lithogenic particle fluxes and grain-size distributions in the deep ocean off northwest Africa: implications for seasonal changes of aeolian dust input and downward transport. Deep-Sea Research I 46, 1289-1337.

Rea, D.K., 1994. The paleoclimatic record provided by eolian deposition in the deep ocean: the geologic history of wind. Reviews of Geophysics 32, 159-195.

Rea, D.K., Leinen, M., Jacenek, T.R., 1985. Geologic approach to the long-term history of atmospheric circulation. Science 227, 721-725.

Reille, M., Lowe, J.J., 1993. A re-evaluation of the vegetation history of the Eastern Pyrénées (France) from the end of the glacial to the present. Quaternary Science Reviews 12, 47-77.

Rivas-Martinez, S., 1982. Etages bioclimatiques, secteurs chronologiques et séries de végétation de l'Espagne méditerranéenne. Ecologia

Mediterranea 8, 275-288. 
925 Robert, C., Gauthier, A., Chamley, H., 1984. Origine autochtone et allochtone des argiles 926 récentes de haute altitude en Corse. Géologie de la Méditerranée XI, 243-253.

927 Rodríguez, S., Querol, X., Alastuey, A., Kallos, G., Kakaliagou, O., 2001. Saharan dust 928 contributions to PM10 and TSP levels in Southern and Eastern Spain. Atmospheric 929 Environment 35, 2433-2447.

930 Rognon, P., Coudé-Gaussen, G., Revel, M., Grousset, F.E., Pédemay, P., 1996. Holocene 931 Saharan dust deposition on the Cape Verde islands: sedimentological and $\mathrm{Nd}-\mathrm{Sr}$ isotopic 932 arguments. Sedimentology 43, 359-366.

933 Rohling, E.J., Hayes, A., de Rijk, S., Kroon, D., Zachariasse, J.W., 1998. Abrupt cold spells 934 in the NW Mediterranean. Paleoceanography 13, 316-322.

935 Roucoux, K.H., de Abreu, L., Shackleton, N.J., Tzedakis, P.C., 2005. The response of NW 936 Iberian vegetation to North Atlantic climate oscillations during the last 65 kyr. Quaternary 937 Science Review 24, 1637-1653.

938 Ruddiman, W.F., 1997. Tropical Atlantic terrigenous fluxes since 25,000 yr. Marine Geology $939136,18-207$.

940 Ruddiman, W.F., Sarnthein, M., Backman, J., Baldauf, J.G., Curry, W., Dupont, L.M., 941 Janecek, T., Pokras, E.M., Raymo, M., Stabell, B., Stein, R., Tiedemann, R., 1989. Late 942 Miocene to Pleistocene evolution of climate in Africa and the low-latitude Atlantic: overview 943 of leg 108 results. In: Ruddiman, W.F., Sarnthein, M., et al., (Eds.), Proceedings of the Ocean 944 Drilling Program, Scientific Results, pp. 463-484.

945 Sánchez-Goñi, M.F., Cacho, I., Turon, J.L., Guiot, J., Sierro, F.J., Peypouquet, J.-P., Grimalt, 946 J.O., Shackleton, N., 2002. Synchroneity between marine and terrestrial responses to 947 millennial scale climatic variability during the last glacial period in the Mediterranean region. 948 Climate dynamics 19, 95-105.

949 Sarnthein, M., Thiede, J., Pflaumann, U., Erlenkeuser, H., Fütterer, D., Koopmann, B., Lange, 950 H., Seibold, E., 1982. Atmospheric and oceanic circulation patterns off Northwest Africa 951 during the past 25 million years. In: Rad, U., Hinz, K., Sarnthein, M., Seibold, E. (Eds.), 952 Geology of the Northwest African Continental Margin. Springer, Berlin, pp. 545-604.

953 Schütz, L., 1980. Long-range transport of desert dust with special emphasis on the Sahara. 954 Annual of the New York Academy of Science 338, 515-532. 
955 Singer, A., Galan, E., 1984. Palygorskite-Sepiolite. Occurences, Genesis and Uses. 956 Developments in Sedimentology. Elsevier, Amsterdam.

957 Snoussi, M., Jouanneau, J.M., Latouche, C., 1990. Flux de matières issues des bassins 958 versants de zones semi-arides (bassin du Sebou et du Souss, Maroc). Importance dans le bilan 959 global des apports d'origine continentale parvenant à l'océan mondial. Journal of African 960 Earth Sciences 11 (1-2), 43-54.

961 Stanley, D.J., Warne, A.G., Davis, H.R., Bernasconi, S.M., Chen, Z., 1992. Nile delta. 962 National Geographic Research Exploration 8 (1), 22-51.

963 Tarasov, P.E., Cheddadi, R., Guiot, J., Bottema, S., Peyron, O., Belmonte, J., Ruiz-Sanchez, 964 V., Saasi, F., Brewer, S., 1998. A method to determine warm and cool steppe biomes from 965 pollen data: application to the Mediterranean and Kazakhstan regions. Journal of Quaternary 966 Science 13, 335-344.

967 Tomadin, L., 2000. Sedimentary fluxes and different dispersion mechanisms of the clay 968 sediments in the Adriatic basin. Rendiconti Scienze Fisiche e Naturali Accademia Lincei 9 969 (11), 161-174.

970 Tomadin, L., Lenaz, R., 1989. Eolian dust over the Mediterranean and their contribution to 971 the present sedimentation. In: Leinen, M., Sarnthein, M. (Eds.), Paleoclimatology and 972 Paleometeorology: Modern and Past Patterns of Global Atmospheric Transport. Series C/ 973 Mathematical and Physical Sciences. Kluwer academic, Dordrecht, pp. 267-281.

974 Torres-Padrón, M.E., Gelado-Caballero, M.D., Collado-Sánchez, C., Siruela-Matos, V.F., 975 Cardona-Castellano, P.J., Hernández-Brito, J.J., 2002. Variability of dust inputs to the 976 CANIGO zone. Deep-Sea Research II 49, 3455-3464.

977 Tzedakis, P.C., 2005. Towards an understanding of the response of southern European 978 vegetation to orbital and suborbital climate variability. Quaternary Science Reviews 24, $979 \quad 1585-1599$.

980 Walter, W., Harnickell, E., Mueller-Dombois, D., 1975. Climate-Diagram Maps. Springer, 981 Berlin.

982 Washington, R., Todd, M.C., 2005. Atmospheric controls on mineral dust emission from the 983 BodéléDepression, Chad: the role of the low level jet. Geophysical Research Letters 32 984 (L17701). 
985 Watts, W.A., Allen, J.R.M., Huntley, B., 1996. Vegetation history and palaeoclimate of the 986 last glacial period at Lago Grande di Monticchio, southern Italy. Quaternary Science Reviews $987 \quad 15,133-153$.

988

989 


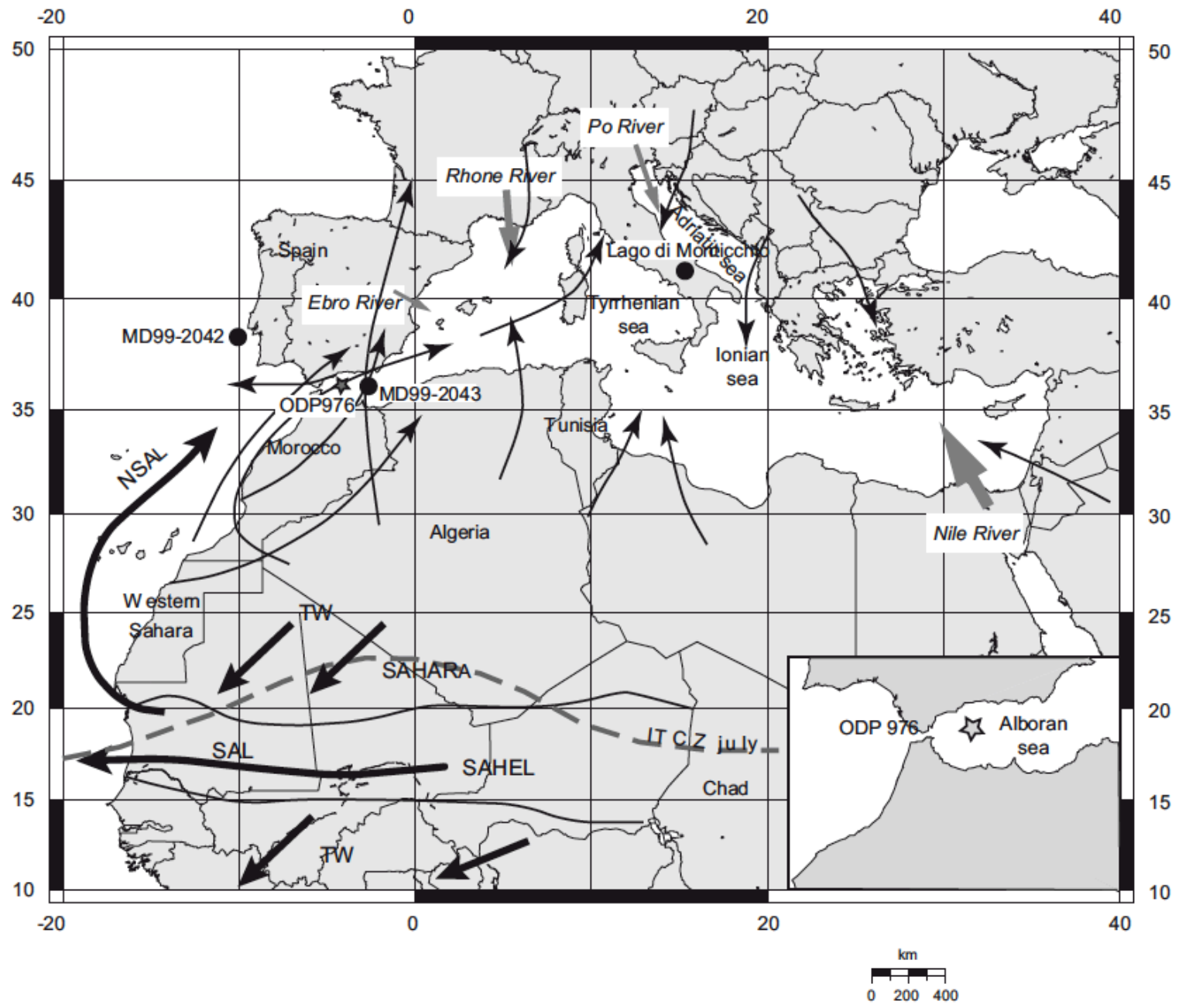

992 Fig. 1. Geographical settings. Main wind trajectories (black arrow) and rivers supply (gray

993 arrow) in the Mediterranean area. The geographical boundary between Sahara and Sahel is 994 reported. SAL: Saharan air layer, TW: northeast trade winds, NSAL: northern branch of the 995 SAL, ITCZ July: position of the Inter-Tropical Convergence Zone in July. 

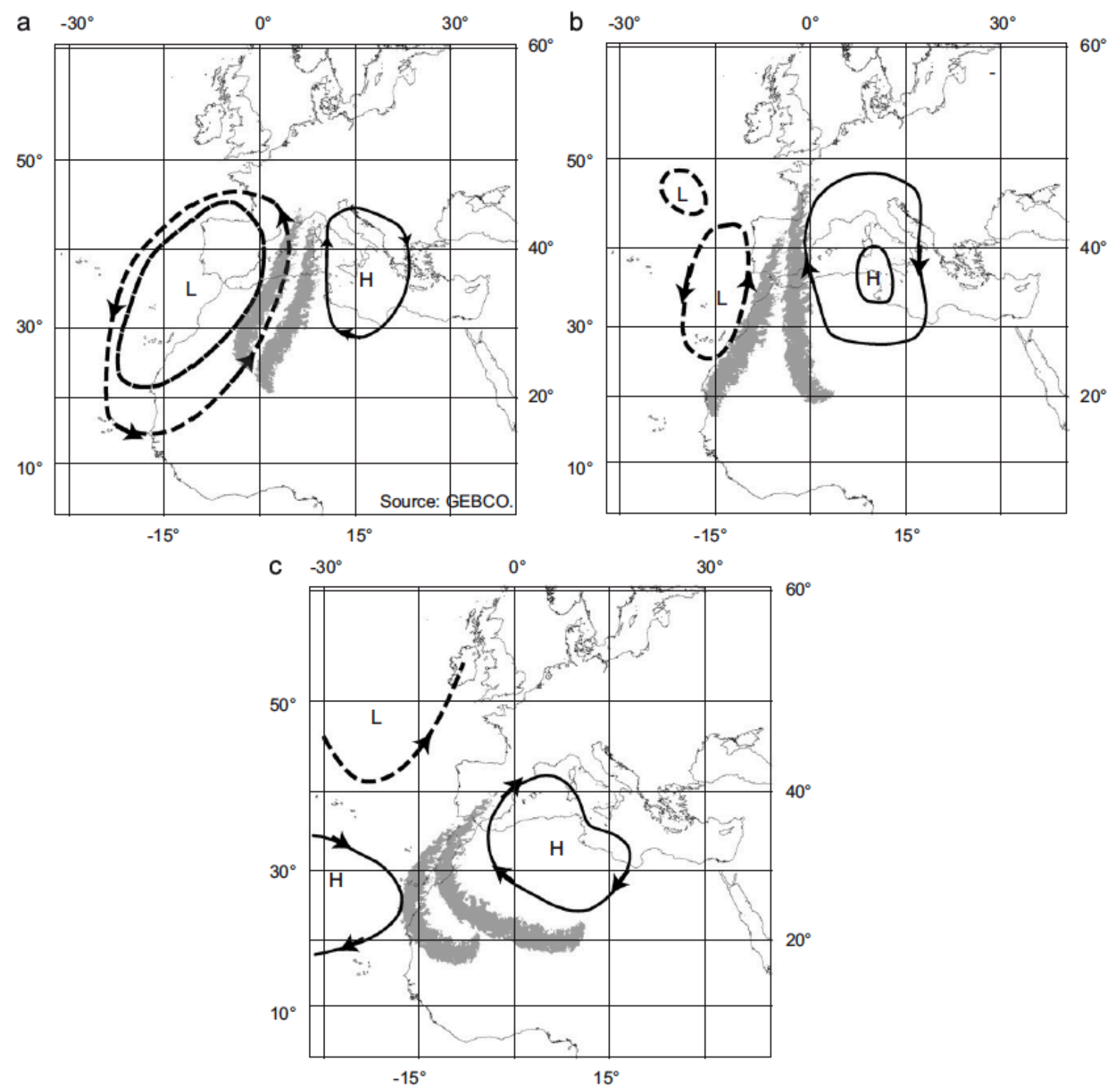

998 Fig. 2. Three main atmospheric configurations favouring the meridian transport of Saharan 999 dust toward Europe during winter (a) strong low pressure (L) over the Iberian peninsula, 1000 during fall (b) strong high pressure $(\mathrm{H})$ over central Mediterranean combined with a low 1001 pressure off Portugal, and during summer (c) strong low pressure over North Africa and 1002 tropical Atlantic and low pressure over North Atlantic. Modified from (Coudé-Gaussen, 1982; 1003 Rodríguez et al., 2001). 

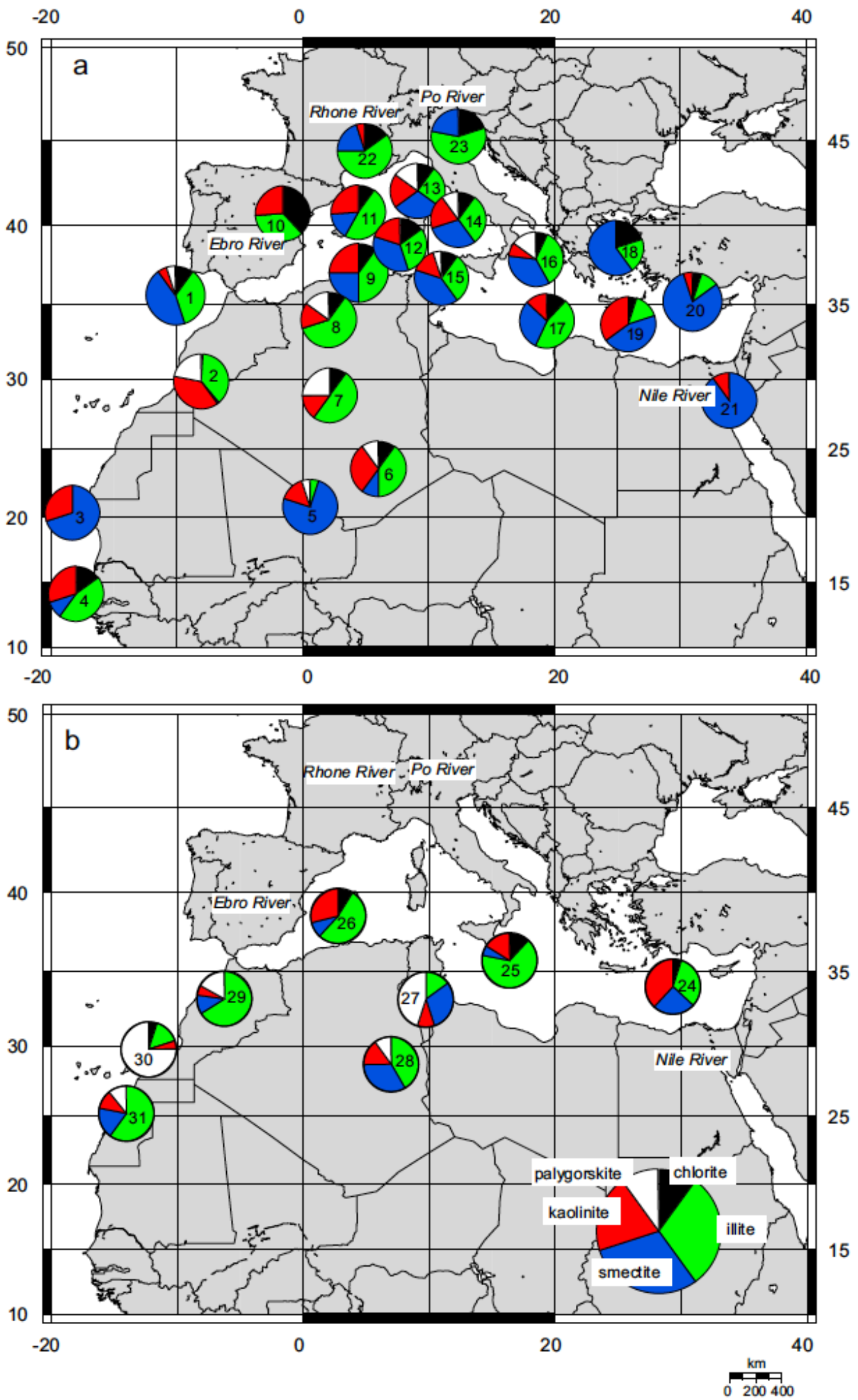
1006 Fig. 3. Clay mineralogy of (a) peri-Mediterranean river particles and sediments (in \%) and (b) 1007 dust and aerosols (Pastouret et al., 1978; Coudé-Gaussen, 1982; Paquet et al., 1984; Robert et 1008 al., 1984; Chamley, 1989; Alonso and Maldonado, 1990; Grousset et al., 1992; Avila et al., 1009 1997; Guerzoni et al., 1999; El Mouden et al., 2005). 1: Gibraltar, 2: Morocco; 3: Cape blanc, 1010 4: Cape Verde, 5: Tanezrouft, 6: Tamanrasset, 7: In Salah, 8: northern Algeria, 9: Algerian 1011 shelf, 10: Ebro river, 11: western Mediterranean sediments, 12: Sardinia, 13: Corsica, 14: 1012 Tyrrhenian sea, 15: Malta, 16: Ionian sea, 17: central Mediterranean sediments, 18: eastern 1013 Mediterranean sediments, 19: Aegean sea, 20: Florence rise, 21: Nile river, 22: Rhone river, 1014 23: Po river, 24 eastern Mediterranean aerosols, 25: central Mediterranean aerosols, 26: 1015 western Mediterranean aerosols, 27: Tunisian loess, 28: dust from central Algeria, 29: dust 1016 from Moroccan Atlas, 30: Moroccan dust, 31: dust from central Sahara. 


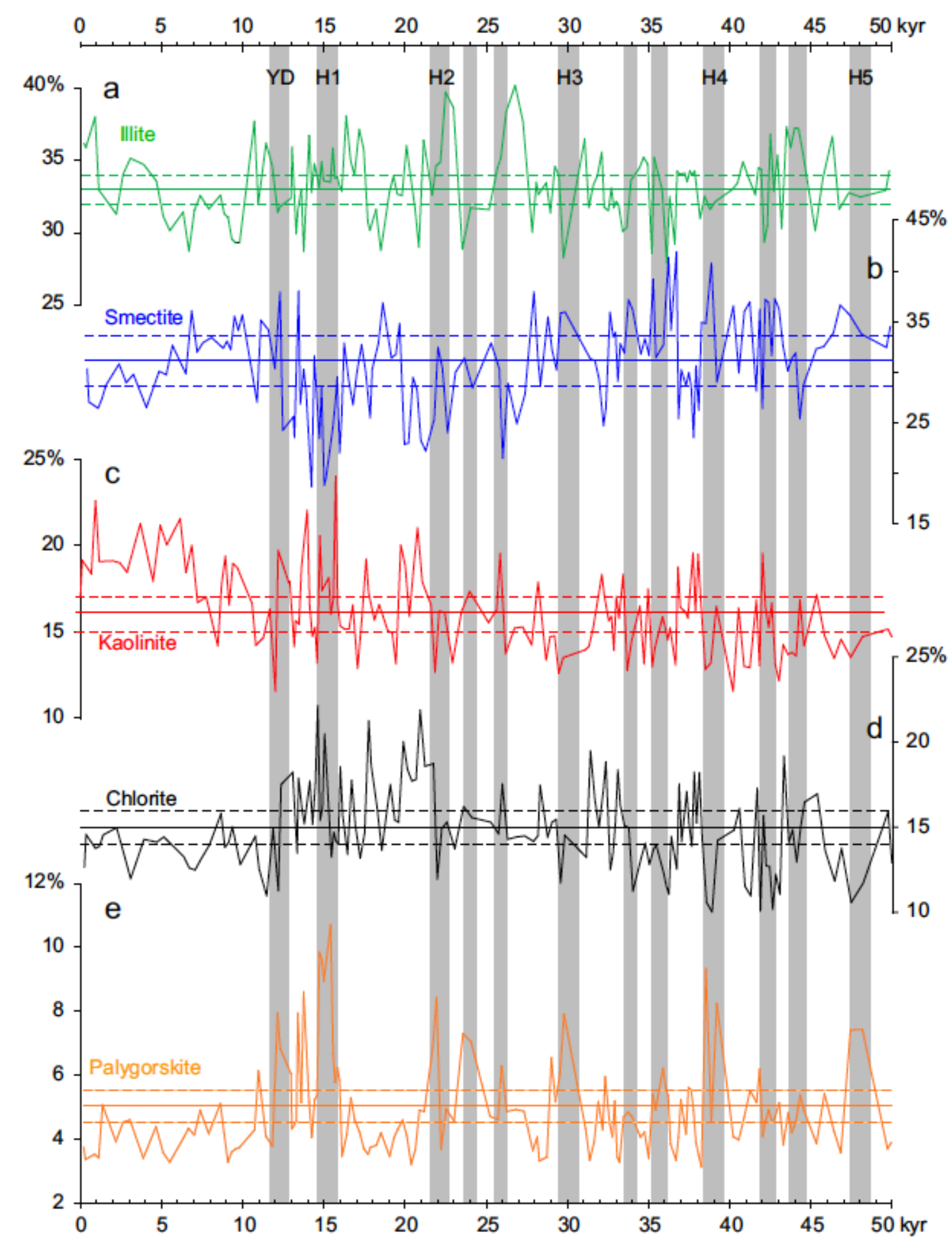

1019 Fig. 4. Clay minerals variations (\%) with time (ka): (a) illite, (b) smectite, (c) kaolinite, (d) 1020 chlorite and (e) palygorskite. Time-slices corresponding to the Younger Dryas (YD) and to 1021 Heinrich events 1 to 5 (H1 to $\mathrm{H} 5)$ are delimited by gray rectangle. 

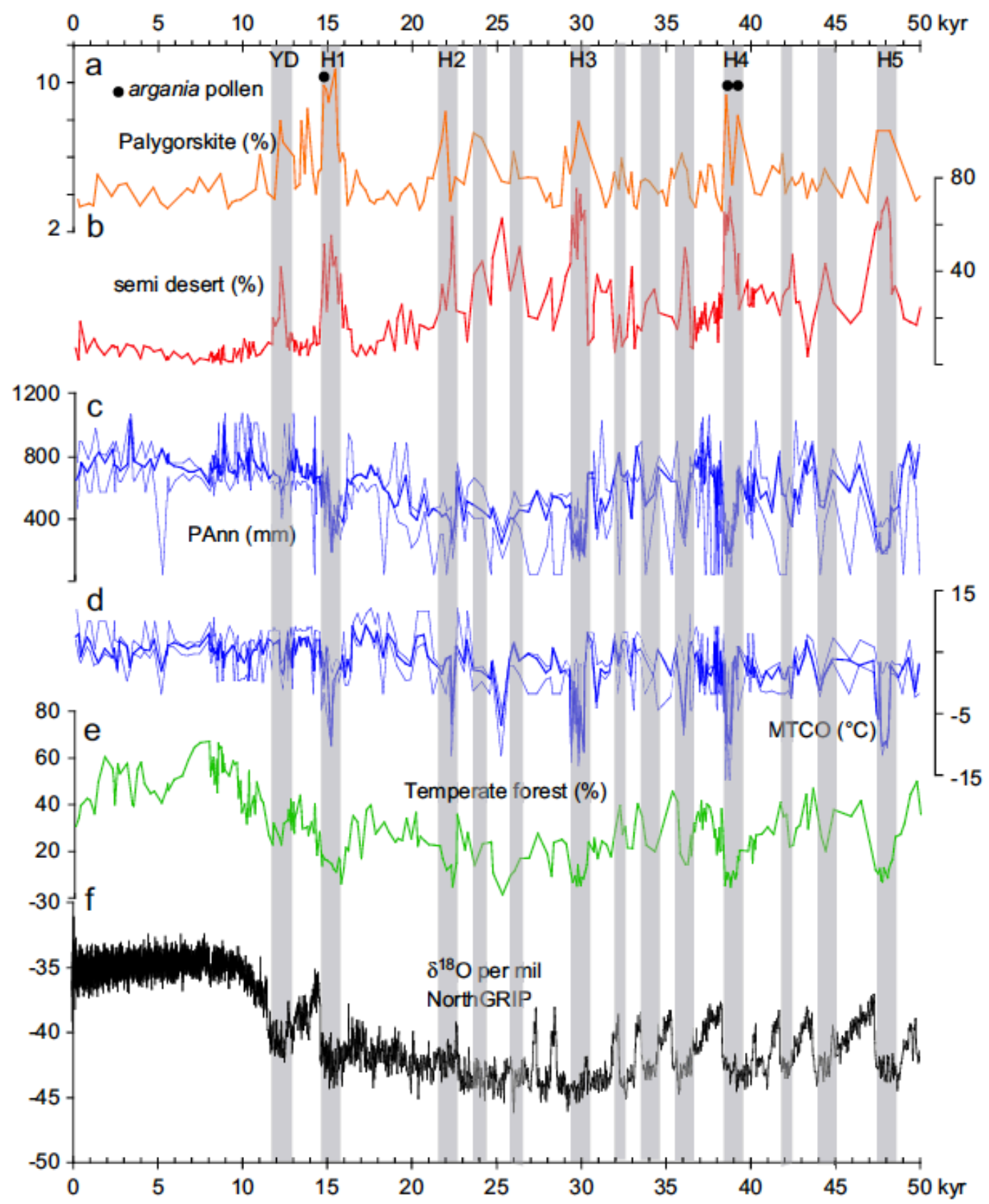

1024 Fig. 5. (a) Palygorskite content (\%), (b) semi-desert vegetation abundance (\%), (c) annual 1025 precipitation (Pann in $\mathrm{mm}$ ) and (d) mean temperature of the coldest month (MTCO) based on 1026 the modern analog technique (see text for explanation) with sigma errors, (e) temperate pollen $1027(\%)$ and (f) oxygen isotopic ratio at NorthGRIP (\%). Time-slices corresponding to the 1028 Younger Dryas (YD) and to Heinrich events 1 to 5 (H1 to H5) are delimited by gray 1029 rectangle. A black circle marks the presence of Argania pollen. 


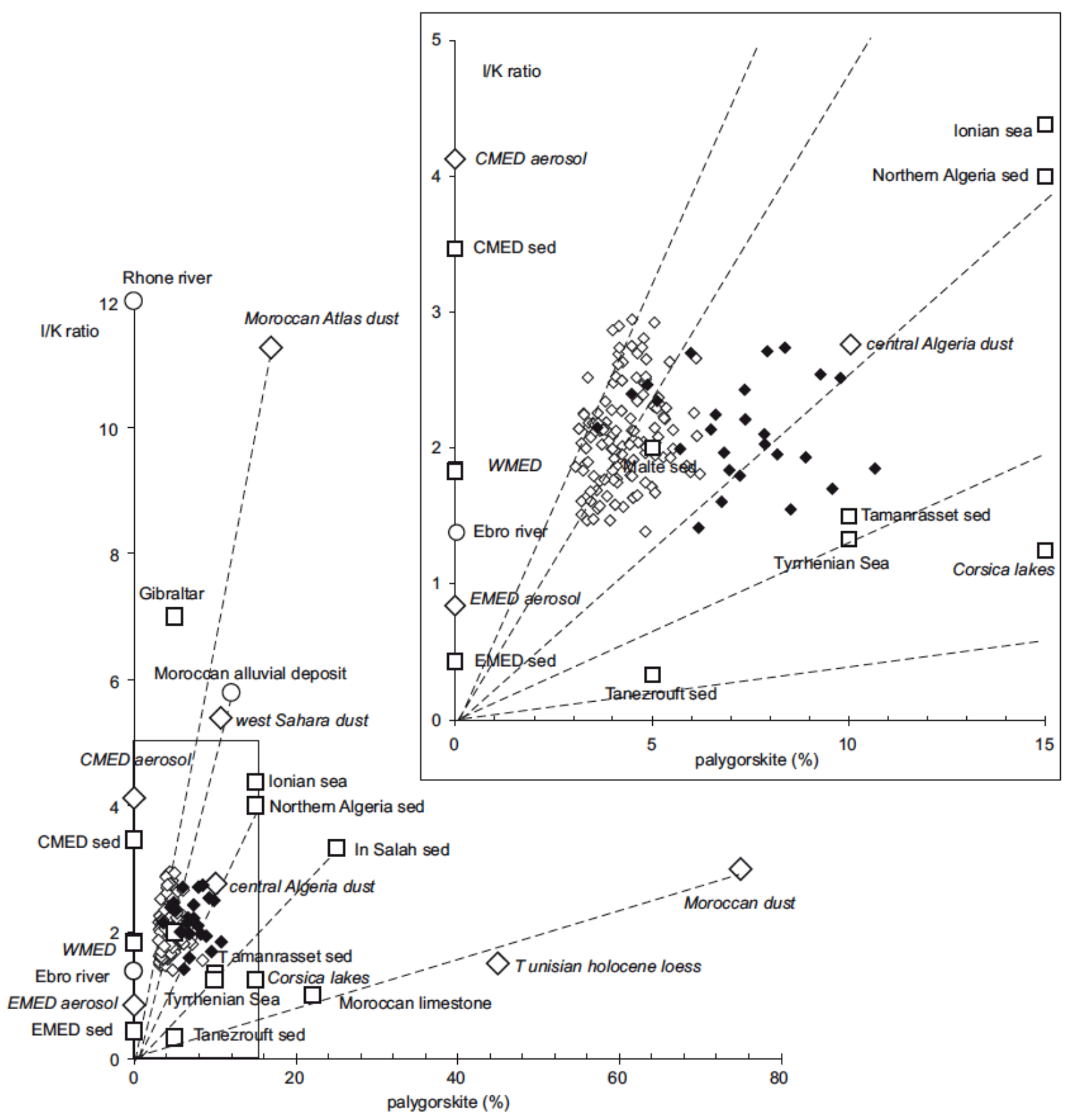

1032 Fig. 6. (a) Palygorskite content (\%) versus illite-to-kaolinite ratio (I/K) of ODP 976 sediments 1033 (diamonds) and of main end-members: rivers (circle), dust and aerosols (star), and sediments 1034 (square). Black diamonds correspond to Younger Dryas and Heinrich events samples. Mixing 1035 lines between end members are suggested (dotted lines), (b) enlarged view of (a). CMED: 1036 central Mediterranean, EMED: eastern Mediterranean, WMED: western Mediterranean. 


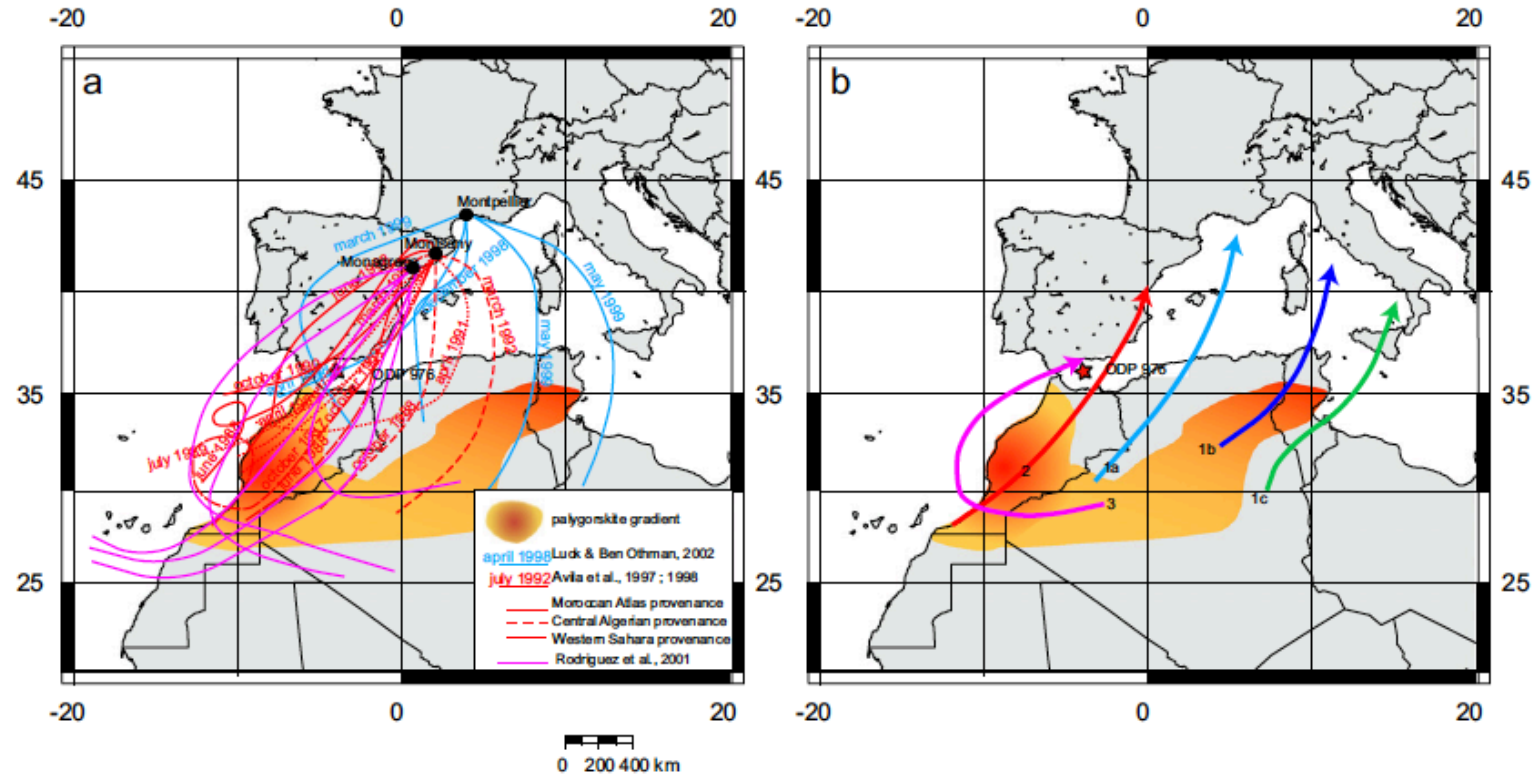

Fig. 7. Main potential sources of palygorskite with gradient ranging from $>25 \%$ (dark orange)

1040 to $10 \%$ (light orange) and (a) main air masses trajectories for different dust events ending at

1041 Montpellier, France (blue lines), Montseny station, Spain (red lines), and Monanegra station,

1042 Spain (pink lines) with respect to their respective origin: thin dotted-line for Moroccan Atlas

1043 provenance; medium dotted-line for central Algeria provenance and thick dotted-line for

1044 western Sahara provenance (Avila et al., 1997; Rodríguez et al., 2001; Luck and Ben Othman, 1045 2002), (b) main average dust trajectories reaching Europe. 

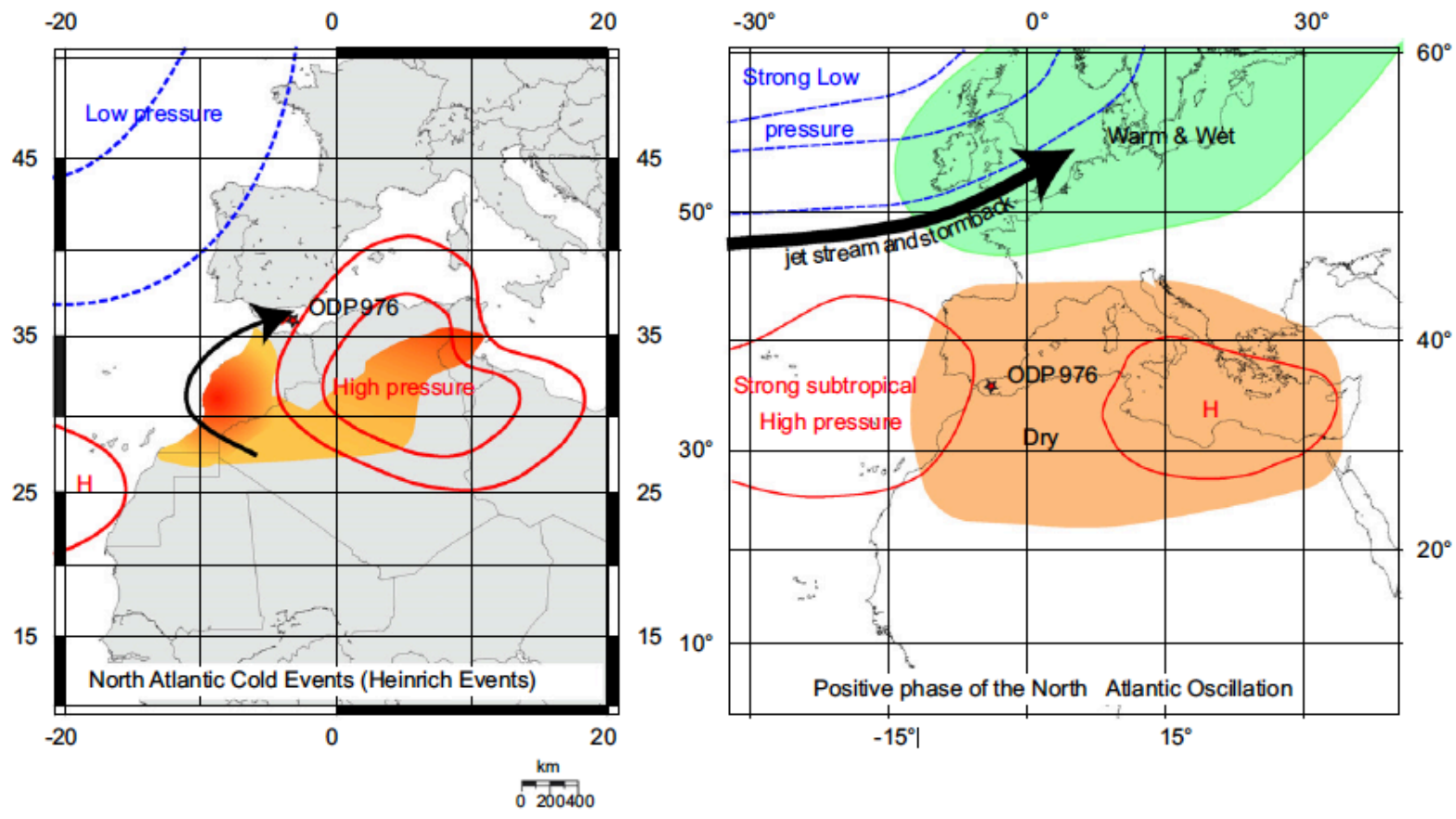

Fig. 8. Synoptic atmospheric configurations over the Mediterranean and the North Atlantic

1049 Ocean (a) during the north Atlantic cold events and (b) associated with positive phase of the 1050 North Atlantic Oscillation (Hurrell, 1995). 